\title{
Detailed Interpretation of Aeromagnetic Data from the Patagonia Mountains Area, Southeastern Arizona
}

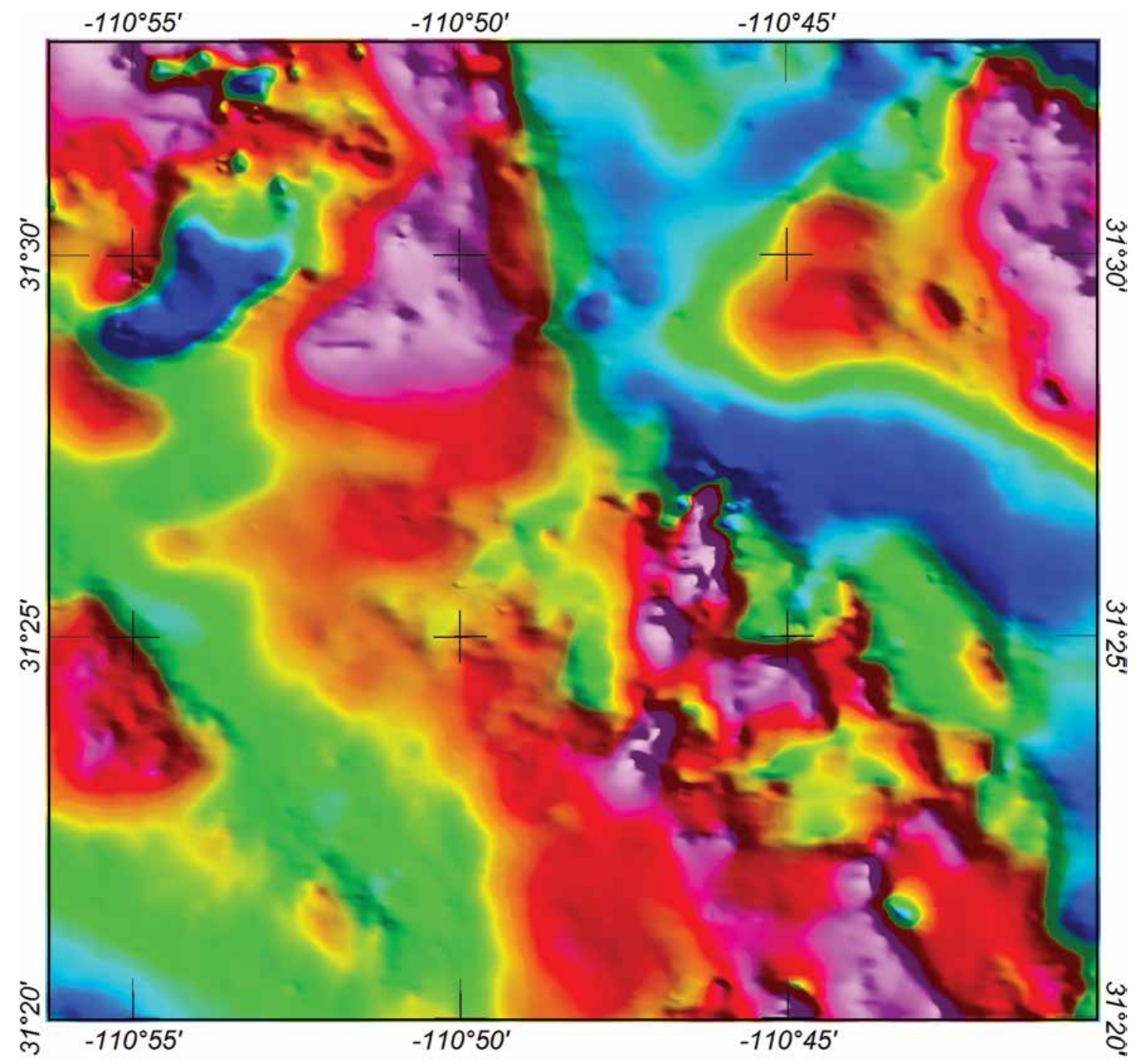

Scientific Investigations Report 2015-5029 
Cover: Aeromagnetic anomaly map of the Patagonia Mountains study areas, southeastern Arizona. 


\section{Detailed Interpretation of Aeromagnetic Data from the Patagonia Mountains Area, Southeastern Arizona}

By Mark W. Bultman

Scientific Investigations Report 2015-5029 


\title{
U.S. Department of the Interior SALLY JEWELL, Secretary
}

\section{U.S. Geological Survey \\ Suzette M. Kimball, Acting Director}

\author{
U.S. Geological Survey, Reston, Virginia: 2015
}

For more information on the USGS - the Federal source for science about the Earth, its natural and living resources, natural hazards, and the environment, visit http://www.usgs.gov or call 1-888-ASK-USGS.

For an overview of USGS information products, including maps, imagery, and publications, visit http://www.usgs.gov/pubprod

To order this and other USGS information products, visit http://store.usgs.gov

Any use of trade, firm, or product names is for descriptive purposes only and does not imply endorsement by the U.S. Government.

Although this information product, for the most part, is in the public domain, it also may contain copyrighted materials as noted in the text. Permission to reproduce copyrighted items must be secured from the copyright owner.

Suggested citation:

Bultman, M.W., 2015, Detailed interpretation of aeromagnetic data from the Patagonia Mountains area, southeastern Arizona: U.S. Geological Survey Scientific Investigations Report 2015-5029, 25 p., http://dx.doi.org/10.3133/ sir20155029.

ISSN 2328-0328 (online) 


\section{Contents}

Abstract
Introduction.
Geology of Patagonia Mountains Region
1996 Patagonia Aeromagnetic Survey
Total Field Magnetic Data
Magnetic Susceptibility of Rock in the Patagonia Mountains Area
Measured Susceptibility, Remanence, and Geology Incorporated into Forward
Complogic Model Modeling
Euler Deconvolution Depth Estimates
Conclusions.

\section{Figures}

1. Map showing location of the Patagonia Mountains study area, southeastern Arizona.

2. Map showing simplified geology and locations of mines, mining districts, and geographic features in the northern part of the Patagonia Mountains study area, southeastern Arizona

3. Geologic map of the Patagonia Mountains study area and surrounding region, southeastern Arizona.

4. Decorrugated aeromagnetic anomaly map of the Patagonia Mountains study area, southeastern Arizona..

5. Map showing results of inversion of $0.5(x) \times 0.5(y)$ by $1.0(z)$ kilometer blocks in the Red Mountain area based on reduced to the pole Earth's magnetic field data, Red Mountain area, southeastern Arizona

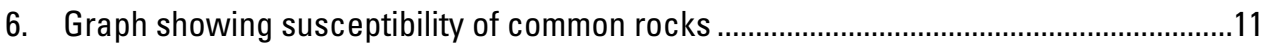

7. Graph showing Koenigsberger ratio of common rocks ..............................................12

8. Diagram showing contribution to the Earth's magnetic field total magnetic intensity from the natural remanent magnetic field based on the angle between

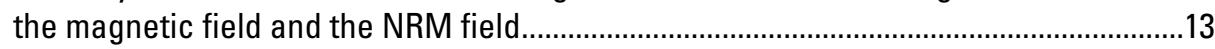

9. Histogram of the base 10 logarithm of susceptibility for samples from the Patagonia Mountains, southeastern Arizona

10. Stereonet plot of samples collected from the Patagonia batholith with reduced total magnetic intensity natural remanent magnetic field and the present-day inductive field of the Earth, Patagonia Mountains study area, southeastern Arizona ...15

11. Geologic cross section for profile 1, Patagonia Mountains study area, southeastern Arizona.

12. Geologic cross section for profile 2, Patagonia Mountains study area, southeastern Arizona. 


\section{Figures-Continued}

13. Complete Bouguer anomaly map of the northern part of the Patagonia Mountains study area, southeastern Arizona

14. Map showing Euler deconvolution depth estimates for a structural index of 0 plotted over aeromagnetic data in the Patagonia Mountains study area, southeastern Arizona

15. Map showing Euler deconvolution depth estimates for a structural index of 1 plotted over aeromagnetic data in the Patagonia Mountains study area, southeastern Arizona

16. Map showing Euler deconvolution depth estimates for a structural index of 2 plotted over aeromagnetic data in the Patagonia Mountains study area, southeastern Arizona

\section{Tables}

1. Map units and physical properties used to develop a geologic model of the Patagonia Mountains, southeastern Arizona

2. Patagonia granodiorite remanent magnetization measurements, Patagonia Mountains study area, southeastern Arizona.

\section{Conversion Factors}

\begin{tabular}{lcl}
\hline \multicolumn{1}{c}{ Multiply } & \multicolumn{1}{c}{ By } & \multicolumn{1}{c}{ To obtain } \\
\hline & Length & \\
\hline centimeter $(\mathrm{cm})$ & 0.3937 & inch $(\mathrm{in})$. \\
meter $(\mathrm{m})$ & 3.281 & foot $(\mathrm{ft})$ \\
kilometer $(\mathrm{km})$ & 0.6214 & mile $(\mathrm{mi})$ \\
\hline \multicolumn{3}{c}{ Mass } \\
\hline metric ton & 1.102 & ton \\
\hline \multicolumn{3}{c}{ Acceleration } \\
\hline milligal $(\mathrm{mGal})$ & $3.281 \times 10^{-5}$ & feet per second squared $\left(\mathrm{ft} / \mathrm{s}^{2}\right)$ \\
\hline \multicolumn{3}{c}{ Magnetic field strength } \\
\hline nT (nanoTesla) & $1.000 \times 10^{-5}$ & gauss $(\mathrm{G})$ \\
\hline \multicolumn{3}{c}{ Magnetic field intensity } \\
\hline amperes $/$ meter $(\mathrm{A} / \mathrm{m})$ & $1.257 \times 10^{-2}$ \\
\hline
\end{tabular}

\section{Datums}

Vertical coordinate information is referenced to the North American Vertical Datum of 1929 (NAVD 29).

Horizontal coordinate information is referenced to the North American Datum of 1927 (NAD 27).

Altitude, as used in this report, refers to distance above the vertical datum. 


\title{
Detailed Interpretation of Aeromagnetic Data from the Patagonia Mountains Area, Southeastern Arizona
}

\author{
By Mark W. Bultman
}

\section{Abstract}

The induced magnetic field and the remanent magnetic field of rock masses are important to geologic modeling based on Earth's magnetic field data. The orientation of the induced magnetic field is approximately parallel to the orientation of Earth's geomagnetic field and its intensity can be derived from measured magnetic susceptibilities of rocks in a study area. The orientation and intensity of the natural remanent magnetic field is much harder to determine; therefore, few investigators have included magnetic remanence as a contributing factor to studies of continental magnetic anomalies. All rocks have remanent magnetism and, in intrusive or volcanic rocks, this component of the total magnetic intensity of the Earth's magnetic field can be as large as or larger than the induced component.

The Patagonia Mountains in southeastern Arizona were selected to produce a subsurface geologic model from aeromagnetic data by incorporating physical properties of rock including measured magnetic susceptibilities, estimated remanent magnetic field orientations and intensities, a known association of intrusive events, and information from existing geologic mapping. The result is a model of geology at depth that may better represent reality than previous poorly substantiated cross sectional models. This new model includes concealed intrusive rocks and defines areas where concealed mineral deposits may be found. It also shows that volcanic rocks might occupy basins at relatively shallow depths in basins with low aeromagnetic anomalies.

Euler deconvolution depth estimates derived from aeromagnetic data with a structural index of 0 show that mapped faults on the northern margin of the Patagonia Mountains generally agree with the depth estimates in the new geologic model. The deconvolution depth estimates also show that the concealed Patagonia Fault southwest of the Patagonia Mountains is more complex than recent geologic mapping represents. Additionally, Euler deconvolution depth estimates with a structural index of 2 locate many potential intrusive bodies that might be associated with known and unknown mineralization.

\section{Introduction}

Since at least 1938, geoscientists have known that remanent magnetism in rocks (termed natural remanent magnetism) can be an important or dominant component of Earth's magnetic field measured at the surface of the Earth (Koenigsberger, 1938a, 1938b). The natural remanent magnetization of igneous, volcanic, and sedimentary rocks is a vector magnetic field that the rock acquires when it is formed whose direction can be used to help interpret rotation since that time by comparing it to Earth's current (2014) magnetic field (Koenigsberger, 1938a, 1938b).Vine and Matthews (1963) associated patterns of magnetic striping emanating from ocean spreading ridges to reversals of the Earth's geomagnetic field, which helped lead to an understanding of both geomagnetic reversals and plate tectonics. Clearly, natural remanent magnetism in rocks is an important concept in modeling the geology responsible for anomalies in the Earth's magnetic field. Few investigators, however, have included natural remanent magnetism as a contributing factor to studies of continental magnetic anomalies (Morris and others, 2007). Considering that many rock masses have natural remanent magnetism recorded with a field direction significantly different from the direction Earth's current magnetic field, this is startling and may reduce the accuracy of many published interpretations.

Caution must be used when modeling geologic anomalies in the Earth's magnetic field in areas that include rocks with a natural remanent magnetism with a field direction different from the direction of the Earth's current magnetic field. Interpretations based on transformations often performed on aeromagnetic survey data, including reduction to the pole, various forms of filtering, and some depth-to-source estimation techniques are not valid for magnetic fields with natural remanent magnetization directions other than that of the inducing field (Gettings, 2002). Additionally, Saltus and Blakely (2011) argued that geophysical interpretations become more constrained when information such as geological mapping, rock physical property measurements, and results from other geophysical methods are included in a geophysical interpretation. 
The Patagonia Mountains area of southeast Arizona (fig. 1) is a geologically diverse region with intrusive, extrusive, and sedimentary rocks and a complicated geologic history. In 1996, the USGS contracted to acquire an aeromagnetic map over this region and the adjacent Santa Cruz Valley and Santa Rita Mountains (U.S. Geological Survey, 2000; Gettings, 2002). These aeromagnetic data have been used by several studies to make interpretations of the Patagonia Mountains and surrounding areas including Gettings (2002), Phillips (2002), Rystrom and others (2002), and Berger and others (2003). Gettings (2002) notes “... that some of the reversely polarized rocks indicate paleomagnetic directions that are not parallel (or anti-parallel) to the current induction direction, it is clear that in much of the survey area, remanent magnetization is an important, sometimes dominant, component of the magnetic anomaly." Additionally, Hagstrum (1994) presents measured paleomagnetic vectors on some of the intrusive and extrusive rocks in this area, many of which include directions not aligned with the current magnetic field of Earth. Because of the importance of remanent magnetism in this region and the availability of age and remanent magnetic vector information for some rocks, the Patagonia Mountains area was selected to study the use of incorporating detailed geologic information, including measured susceptibilities and published remanence vectors, into an interpretation of the 1996 aeromagnetic survey of the Patagonia Mountains area.

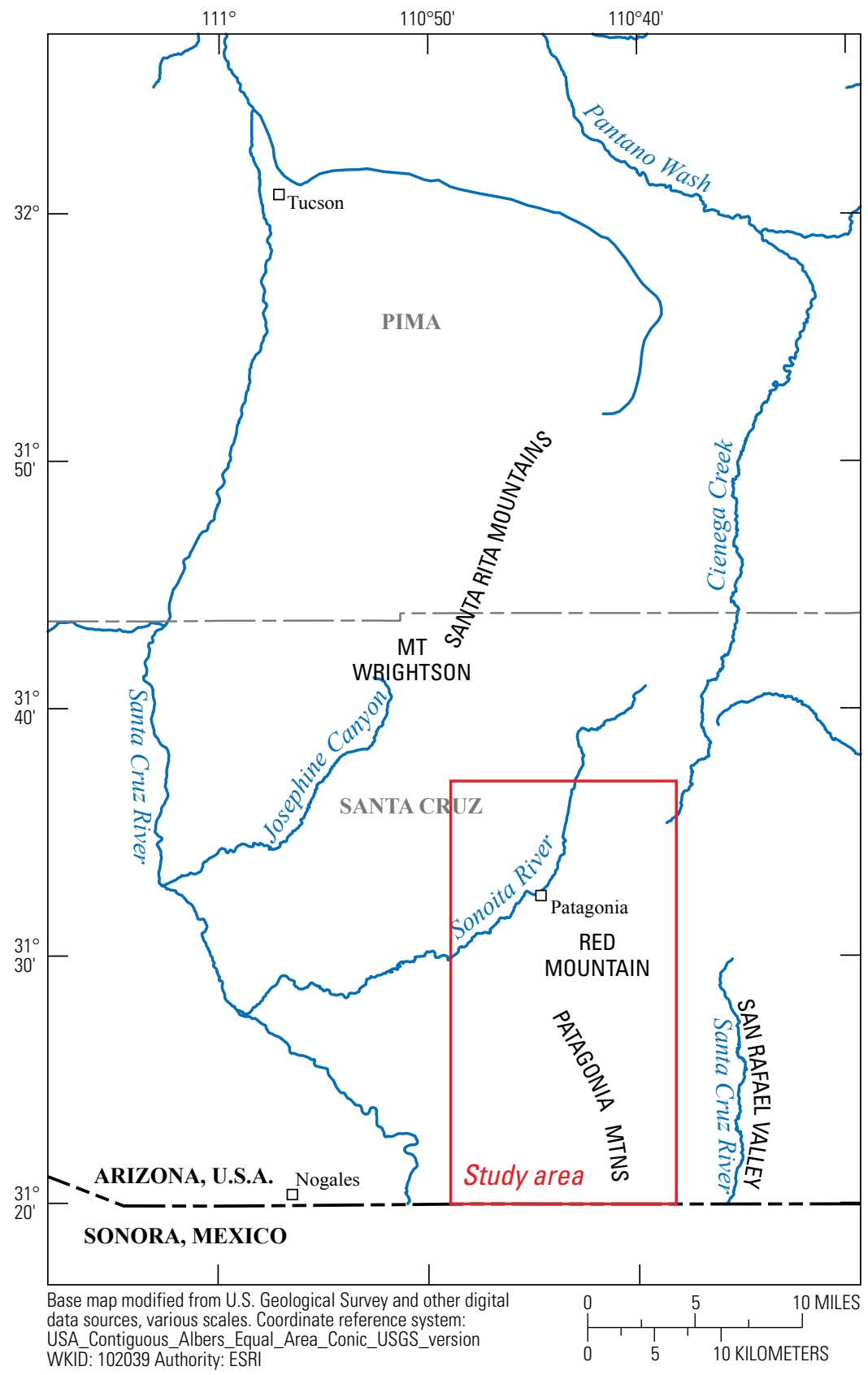

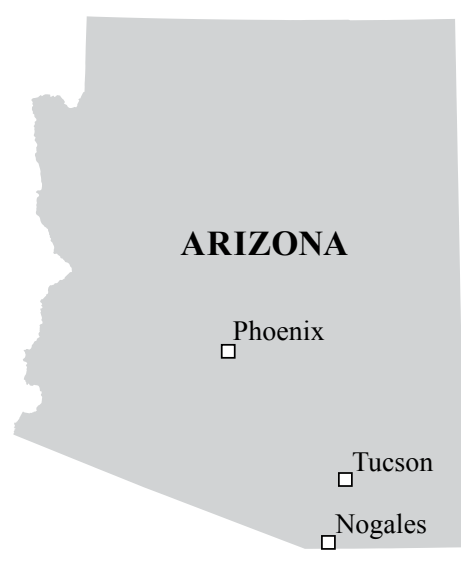

Figure 1. Location of the Patagonia Mountains study area, southeastern Arizona. 
This report provides an overview of the geology of the Patagonia Mountains region and reviews several geophysical analyses in the region. The known geology of the region was used to create a model of the geology in cross section for two aeromagnetic profiles. It proposes that the large aeromagnetic low anomaly in the study area is caused by a concealed intrusion with a natural remanent magnetism direction that is not aligned to the direction of the Earth's current magnetic field. It concludes by looking at Euler depth estimates (which are not affected by rocks with nonaligned natural remanent magnetism) in the region to see if they corroborate the findings in the model and if they provide any new insight into the geology of this region.

\section{Geology of Patagonia Mountains Region}

The geology of the Patagonia Mountains area is shown in figure 2 (general geology with mines and other geographic labels; Berger and others, 2003) and figure 3 (geologic map; Drewes, 1980; Drewes and others, 2002). An explanation of map units in figure 3 is provided in table 1. Precambrian basement rocks include biotite-quartz monzonite and hornblende diorite to the east of the Patagonia Mountain range and biotite-hornblende quartz monzonite and hornblende gabbro on the west side (Simons, 1974). Small outcrops of Precambrian pelitic schist, diorite, and gabbro also can be found in the area (Simons, 1974; Drewes, 1980). Paleozoic sedimentary rocks are present in two areas: (1) on the east side of the Patagonia Mountains where quartzites, limestones, and dolomites outcrop, and (2) in small brecciated blocks of shear-bounded limestone that crop out at the Flux Mine and are enclosed in late Triassic to lower Jurassic volcanic and volcaniclastic rocks (Simons, 1974, Drewes, 1980). Several similar limestone blocks are north of the Chief Mine. These limestone blocks are thought to be Permian in age and were interpreted by Lipman and Sawyer (1985) to be fragments of a Jurassic caldera complex. Throughout most of the Patagonia Mountains, Paleozoic carbonate rocks are intruded either by granitic rocks or in tectonic contact with younger sedimentary rocks (Berger and others, 2003).

Mesozoic rocks in the study area include Triassic to Jurassic, predominantly silicic, volcanic, and sedimentary rocks, including quartzite, sandstone, arkose, and shale (Simons, 1972). These rocks generally are present in a northnorthwest-trending belt on the east side of the main range and as Jurassic granite intruding the Precambrian rocks on the west flank of the range. Cretaceous sedimentary rocks of the Bisbee Formation occur southwest of the Harshaw Creek Fault (map unit Kbu, fig. 3) and consist of siltstone and mudstone with intercalated limestone, sandstone, and conglomerate (Simons, 1974).
A Laramide-age, predominantly quartz monzonite, batholith is present as the core of the central and southern part of the Patagonia Mountains (map unit Ti, fig. 2; map unit Tlg, fig. 3). Vikre and others (2009) defined a succession of six events that formed this batholith, and various mineral deposits that are associated with it, over a period of approximately 17 million years $(74-58 \mathrm{Ma})$. The first event in this sequence is the intrusion of the Washington Camp stock at $74 \mathrm{Ma}$. The skarn deposits at the Washington Camp mining area (copper $[\mathrm{Cu}]$-lead [Pb]-zinc [Zn]-silver [Ag]-gold [Au]-arsenic [As]; fig. 2) are spatially associated with this stock, but some or all of the deposits could be younger. Laramide silicic tuffs, tuff breccias, ash-flow tuffs, and a latite dome are mapped on the southwest side of Red Mountain. Stratigraphically overlying these is the second event in Vikre and others (2009) succession, a widespread $71 \mathrm{Ma}$ trachyandesite event in the area of current Red Mountain and extending to Meadow Valley to the east. Potassium rich mica dated in a vein at the Flux Mine carbonate replacement deposit (Cu-Pb-Zn-Ag-Aumanganese $[\mathrm{Mn}]$ ) are approximately $71 \mathrm{Ma}$, but uncertain paragenetic relations preclude association of the Flux Mine to the trachyandesite volcanism. The Ventura molybdenum (Mo)-Cu breccia deposit (fig. 2) is related to a $65 \mathrm{Ma}$ granodiorite stock, one of several 65-63 Ma small-volume intrusions associated with the Patagonia batholith, which comprises the third event of the succession. Additionally, deposits from the Blue Nose and Morning Glory mines were associated with similar small volume intrusions. At $62 \mathrm{Ma}$, the volcanic rocks of Red Mountain were intruded by a mineralized (chalcopyrite-bornite) quartz monzonite porphyry copper deposit $(\sim 0.6$ billion metric ton [Gt] and 0.6 percent $\mathrm{Cu}, 0.01$ percent $\mathrm{Mo}$ ) and with a near surface secondary enriched chalcocite-enargite resource associated with advanced argillic alteration that is paragenetically younger but not firmly dated. This marked the fourth event in the succession. The $\mathrm{Cu}-\mathrm{Mo}$ breccia deposit at Red Hill (Four Metals Mine), in the southern part of the pluton, may mark a degassing conduit in a large-volume granodiorite event at $60 \mathrm{Ma}$, the fifth event. The Sunnyside porphyry copper system consists of a deep chalcopyrite resource ( $\sim 1.5 \mathrm{Gt}$ and 0.3 percent $\mathrm{Cu}, 0.01$ percent $\mathrm{Mo}$ ), and a nearsurface chalcocite-enargite-tenorite resource is dated at about 61-58 Ma and marks the last event of the succession (Graybeal, 1996; Vikre and others, 2009).

To the east, west, and north of these rocks is a thick sequence of Quaternary and Tertiary gravels (Simons, 1974; Drewes, 1980). Minor tuffs and limestone are included in this unit. The Holocene alluvium that is present in the modern stream channels also is included in this latter unit. 


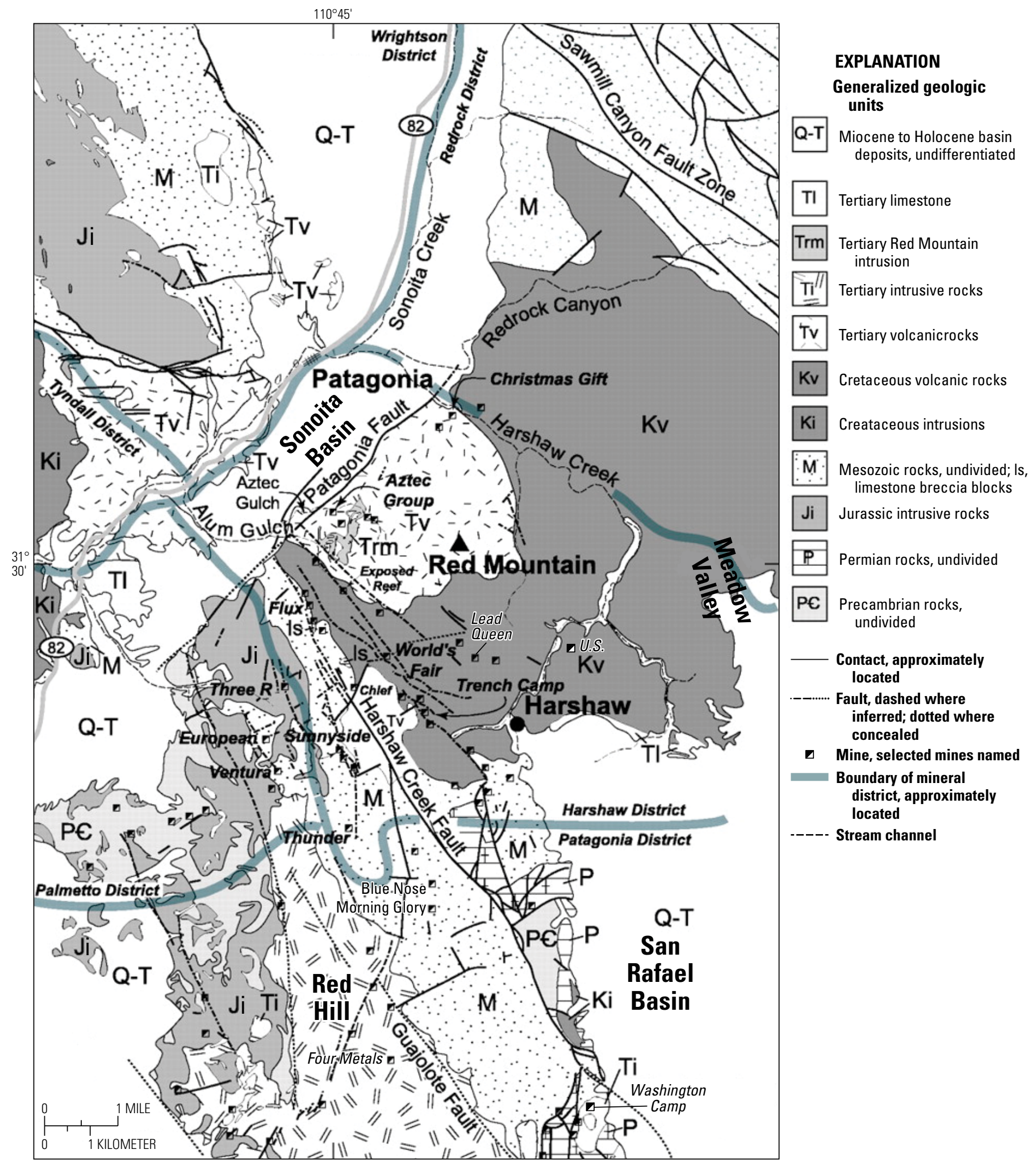

Figure 2. Simplified geology and locations of mines, mining districts, and geographic features in the northern part of the Patagonia Mountains study area, southeastern Arizona. Simplified geology after Berger and others (2003). 


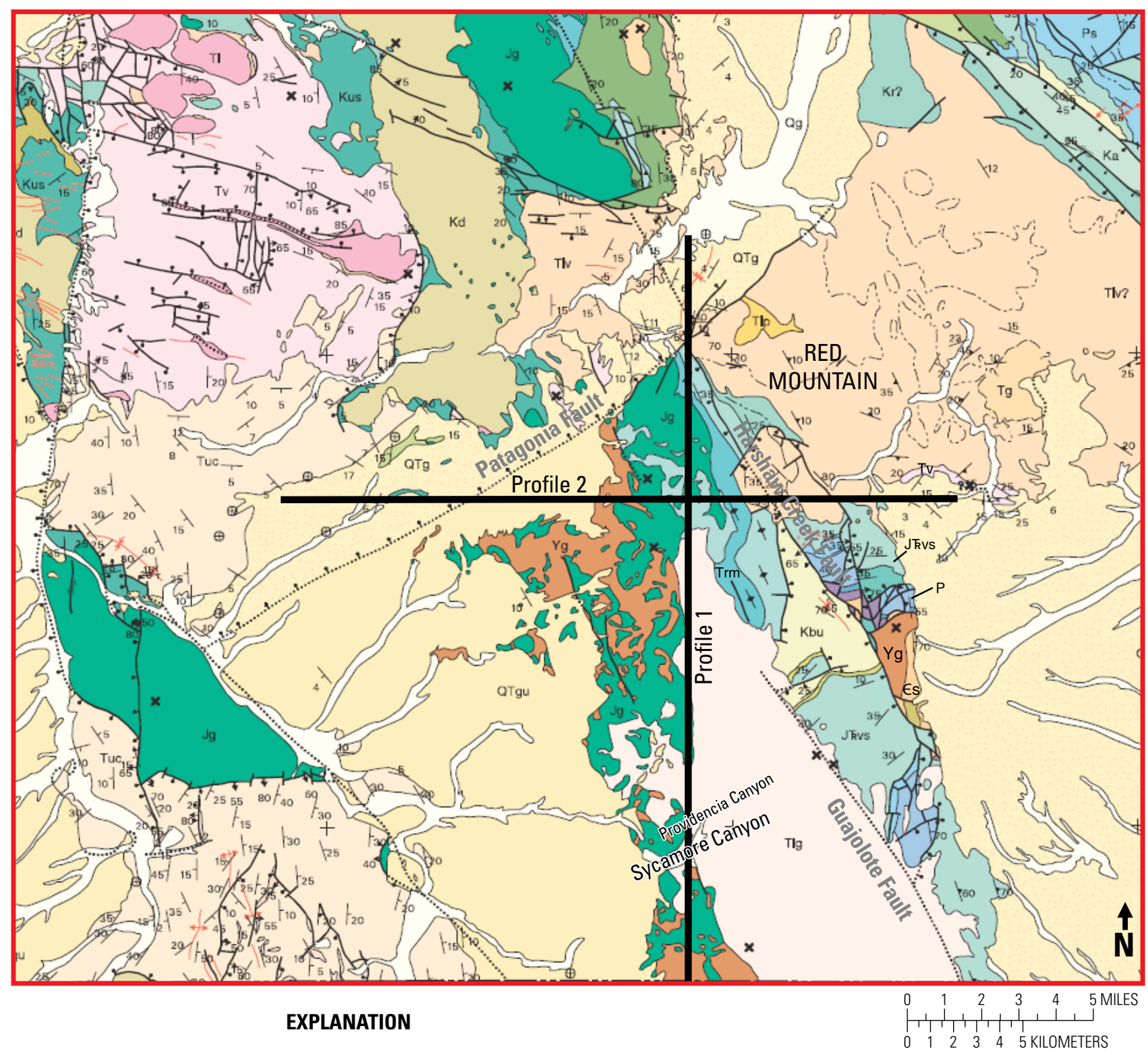

Important map units and description

\begin{tabular}{|c|c|c|c|}
\hline Qtg & \multirow{2}{*}{$\begin{array}{l}\text { Basin fill, unconsolidated } \\
\text { Nogales Formation conglomerate }\end{array}$} & $\mathrm{Jg}$ & Comoro Canyon granite \\
\hline Tuc & & JKvs & Siliceous volcanic and \\
\hline TIV & \multirow{2}{*}{ Rhyolite to andesite } & & sealmentary rocks \\
\hline & & Trm & Mount Wrightson Formation \\
\hline $\mathrm{Tlg}$ & $\begin{array}{l}\text { Biotite-hornblende granodiorite to } \\
\text { quartz monzonite }\end{array}$ & $\mathrm{P}$ & Limestone \\
\hline Kbu & Bisbee formation & $\mathrm{Yg}$ & Hornblende-rich granite \\
\hline & \multicolumn{3}{|c|}{$\begin{array}{l}\text { Contact, approximately } \\
\text { located }\end{array}$} \\
\hline & \multicolumn{3}{|c|}{$\begin{array}{l}\text { —..... Fault, dashed where } \\
\text { inferred; dotted where } \\
\text { concealed }\end{array}$} \\
\hline
\end{tabular}

Figure 3. Patagonia Mountains study area and surrounding region, southeastern Arizona (after Drewes and others, 2002). Geologic map units are described in table 1. Only units used in modeling are included. 


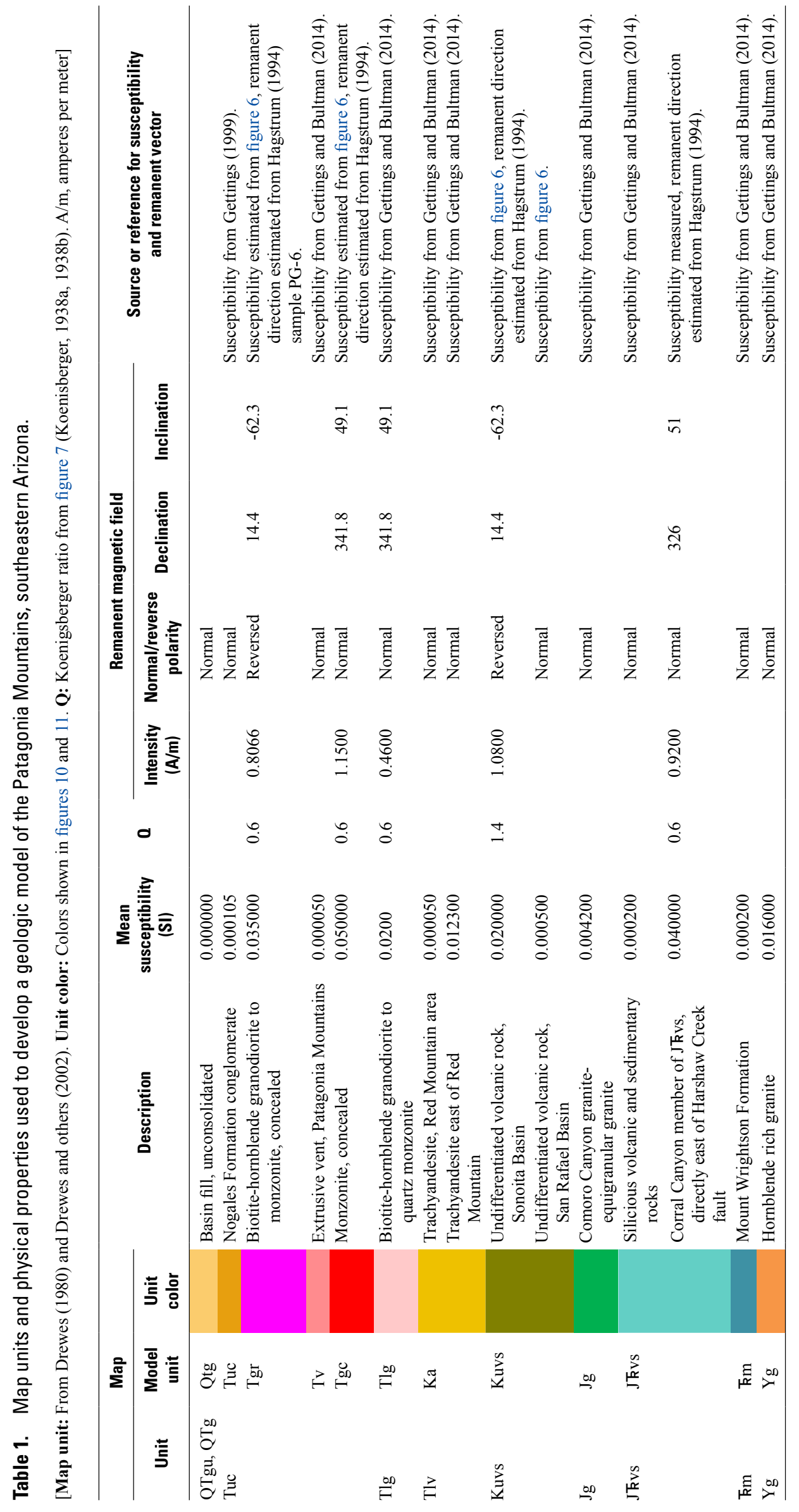


The most prominent faults in the Patagonia Mountains strike northwest, northeast, and east-northeast and likely originated in the Jurassic period. These faults likely had a leftlateral component of displacement during the Jurassic period that changed to reverse and then right-lateral displacement during the latest Cretaceous to early Tertiary periods (Davis, 1981, Berger and others, 2003). Berger and others (2003) show that strike-slip faulting in the Santa Rita Mountains (to the north of the study area) continues south into the Patagonia Mountains (fig. 1). Several parallel strike-slip fault zones with small stepovers mechanically linking them are referred to as the Sawmill Canyon Fault zone (fig. 2) which dominated shear strain accommodation in the region (Berger and others, 2003). Strike-slip zones to the southwest of the Sawmill Canyon Fault zone became linked into it through northeast-striking faults and were locally obscured by thick accumulations of volcanic rocks in structural basins east of Red Mountain within zones of transtension (Berger and others, 2003). In the Patagonia Mountains, the Paleocene Patagonia biotite- hornblende granodiorite batholith (map units Ti, fig. 2 and Tlg; fig. 3) is elongated northwest and bounded by a linear, subparallel fault zone known as the Guajolote Fault (fig. 2). These relations together with cross cutting, northeast-striking faults and veins suggest that the batholith (or related higher level apophyses or cupolas) accommodates extensional strain in-line along the northwest-striking fault zones, and might have been emplaced in an extensional stepover (Berger and others, 2003).

In the Red Mountain topographic block at the north end of the range, there are northeast- striking normal faults and silicified lenses as well as a northeast-striking Tertiary intrusion (map unit Ti; fig. 2). These relations in conjunction with the outcrop of middle Mesozoic sedimentary and volcanic rocks on the southwest side of the Harshaw Creek Fault opposite Red Mountain and their absence to on the northeast side of the fault and beneath the Red Mountain topographic block suggest the possibility that these Late Cretaceous to early Tertiary volcanic rocks and intrusions were localized in an extensional stepover between the Harshaw Creek Fault zone and parallel northwest-striking strike-slip faults to the northeast (Berger and other, 2003).

An area of intense alteration associated with the Red Mountain porphyry copper deposit was mapped by Simons (1974). The area contains the minerals pyrophyllite, sericite, alunite, and (or) kaolinite. In outcrop, much of this area appears strongly bleached and iron-stained as a result of the breakdown of the dark rock-forming minerals and pyrite (Simons, 1974, Corn, 1975).

\section{Patagonia Aeromagnetic Survey}

The U.S. Geological Survey (2000) contracted with Sial Geosciences, Inc. for a detailed aeromagnetic survey of the Santa Cruz Basin and Patagonia Mountains area of south central Arizona in 1996 (U.S. Geological Survey, 2000;
Gettings, 2002). The aeromagnetic data were collected along east-west flight lines spaced $250 \mathrm{~m}$ apart at a terrain clearance of $230 \mathrm{~m}$ (Phillips, 2002). Data also were collected along several widely spaced north-south tie lines that were used to level the flight-line data. The aeromagnetic map gridded from the contractor's flight-line data shows significant streaking or "corrugation" along the flight line direction resulting from level shifts between adjacent flight lines, probably due to the large changes in elevation over the survey area. This corrugation can be corrected for by a technique developed by Urquhart (1988) and implemented by Phillips (1997, 2007). The gridded decorrugated aeromagnetic data from the aeromagnetic survey over the Patagonia Mountains study area are shown in figure 4. Only data from the region are displayed and gridded with a cell size of $50 \mathrm{~m}$, decorrugated, and displayed as a color shaded relief image. Additionally, geologic line work from Drewes (1980) and Drewes and others (2002) (fig. 3) is shown by thin black lines on figure 4 . Also shown in figures 3 and 4 are the locations of profiles 1 and 2 which are parts of aeromagnetic flight lines that were used to build geologic models.

Three interpretations of the 1996 Patagonia aeromagnetic data were published in 2002. Gettings (2002) provided a thorough study and included a comparison of the aeromagnetic data with geologic map data demonstrating correlation of the magnetic anomaly field with mapped geology and shows that numerous map units of volcanic and intrusive rocks from the Jurassic, Cretaceous, and Middle Tertiary have significant natural magnetic remanence. Gettings also performed a textural analysis of the aeromagnetic data, which delineated areas of consistent magnetic anomaly texture for individual exposed lithologies to be extended under sediment cover in Cenozoic basins. Textural measures of the aeromagnetic data (Gettings, 2002) included a number of peaks and troughs per kilometer and Euclidean length per kilometer.

Phillips (2002) used analytic techniques on the 1996 Patagonia aeromagnetic map to delineate contacts and make depth estimates based on three methods of depth estimation. They include the horizontal gradient method, the analytic signal method, and the local wavenumber method. The horizontal gradient method (Cordell and Grauch, 1985; Blakely and Simpson, 1986) is dependent on performing a "reduction to the pole" operation that recalculates total magnetic intensity data as if the inducing magnetic field had a 90-degree inclination. This transformation converts dipolar magnetic anomalies to monopolar anomalies centered over the geologic bodies responsible for the anomaly. Although reduction to the pole can make interpretation easier when the magnetization of the causative bodies is due to magnetic susceptibility, remanent magnetization is not dealt with properly if the direction of remanence is different from the direction of the Earth's magnetic field. The horizontal gradient method has a low sensitivity to noise and its maxima are highly continuous and generally parallel to the contours of the reduced-to-pole aeromagnetic field. Phillips (2002) used the horizontal gradient method to determine the locations of 
physical property (magnetization) boundaries during terracing. Violations of the many assumptions required in the horizontal gradient method can result in displacement of the contacts away from their true locations. The displacement is typically down dip from the true contact location (Grauch and Cordell, 1987). The analytic signal method and the local wavenumber method are very sensitive to noise in the data, but provide contacts between units of contrasting susceptibility that are less continuous than the horizontal gradient method. Rystrom and others (2002) performed a similar analysis as Phillips (2002) and were able to show that many geologic map units displayed unique magnetic properties. Phillips (2002) and Rystrom and others (2002) successfully used the 1996
Patagonia aeromagnetic data to delineate known geologic map features. Because they used methods that are affected by rocks with natural magnetic remanence, caution should be used on estimates of depth to source in these analyses.

In another analysis of the 1996 Patagonia aeromagnetic data, Berger and others (2003) presented a three-dimensional inversion for magnetic susceptibility of total field aeromagnetic data that used ModelVision Pro $^{\mathrm{TM}}$ software to estimate the magnetic susceptibility of the near-surface materials near Red Mountain. The inversion was based on 506 vertical prisms each having dimensions of $0.5(\mathrm{x}) \times$ $0.5(\mathrm{y}) \times 1.0(\mathrm{z}) \mathrm{km}$. Using prisms of that size assumed that all the magnetic material producing observed anomalies

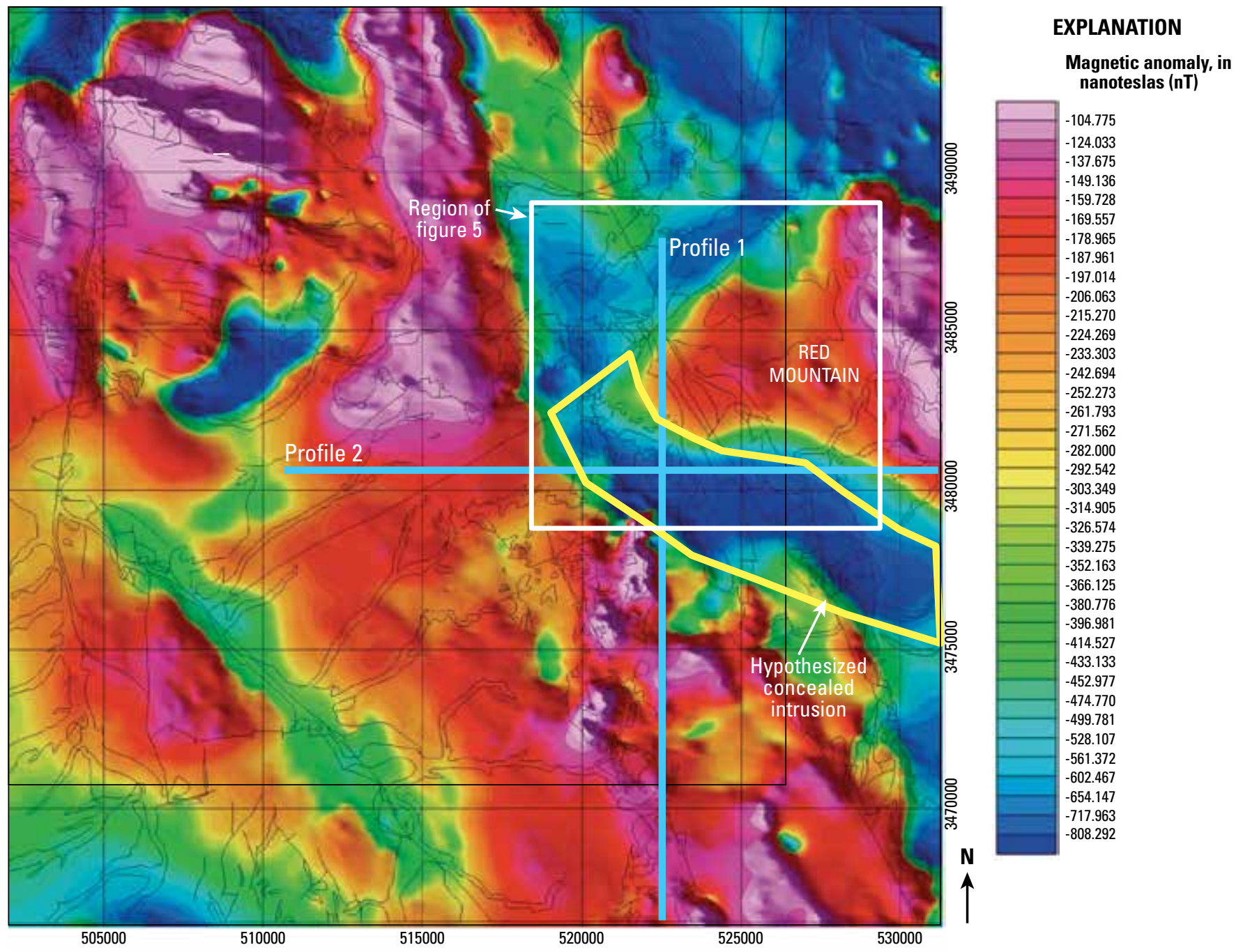

Figure 4. Decorrugated aeromagnetic anomaly map of the Patagonia Mountains study area, southeastern Arizona. Overlain geologic linework (black lines) from Drewes and others (2002). 
was in a layer $1 \mathrm{~km}$ thick, having its top at the topographic surface. The magnetization boundaries that were estimated from reduced-to-pole aeromagnetic data using the horizontal gradient method were included (Berger and others, 2003). Additionally, low and negative susceptibilities produced by the inversion (fig. 5) for rock masses south of Red Mountain are indicative of nonmagnetic basin-fill material overlying weakly magnetized basement rocks adjacent to the range (Berger and others, 2003). There are magnetization boundaries within the region of low magnetic susceptibility as it crosses the Patagonia Mountains between Trench Camp and the Three $\mathrm{R}$ Mine indicating the rocks within the range are relatively weakly magnetized (fig. 5). According to Berger and others (2003, p. 1,009), "Because intrusive rocks at the Three R, European, and Ventura mines are the same composition as those with high magnetic susceptibility to the west and southwest in figure 5, it is assumed that some of the low susceptibility on the west side of the range is due to hydrothermal alteration."

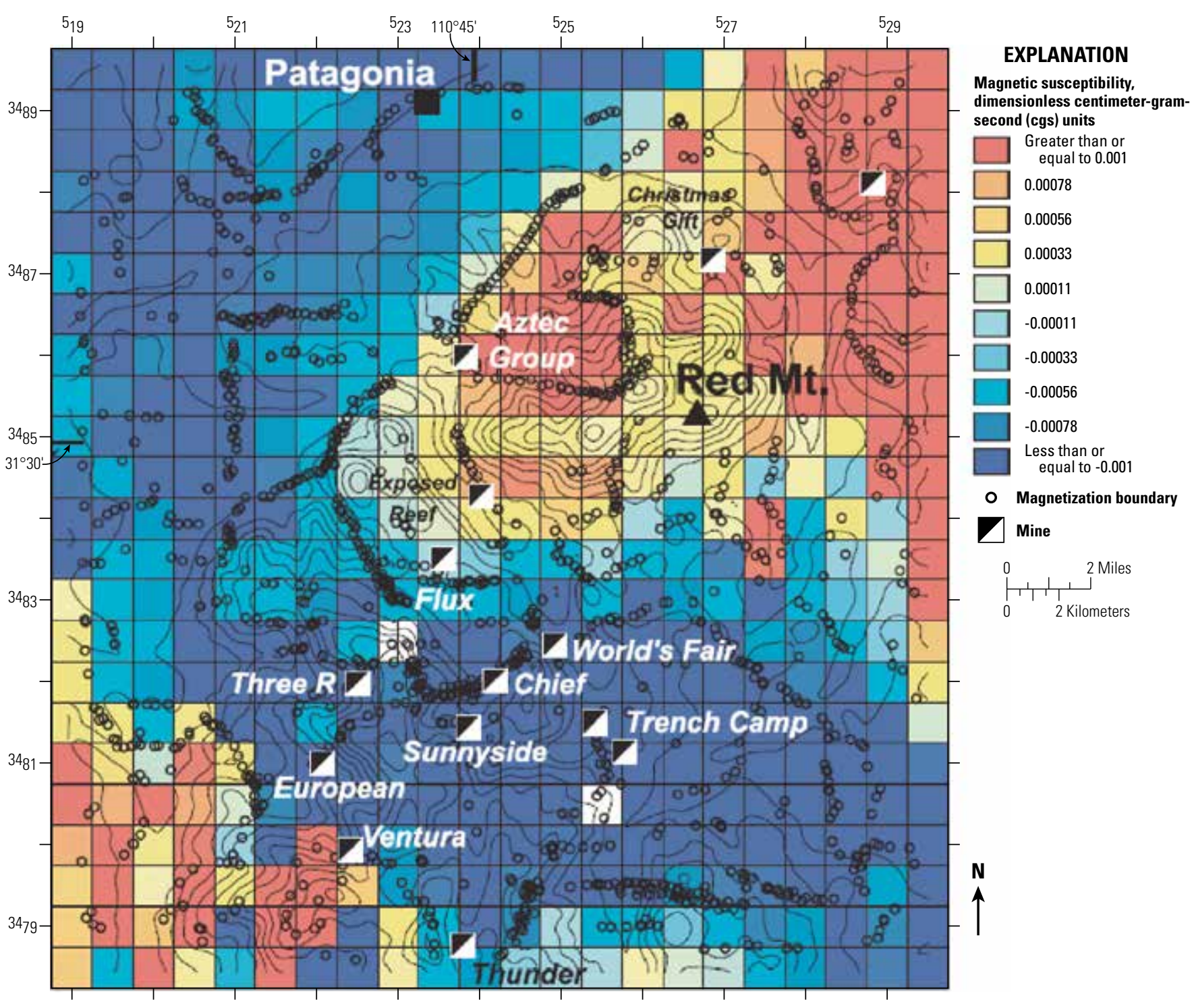

Figure 5. Results of inversion of $0.5(\mathrm{x}) \times 0.5(\mathrm{y})$ by $1.0(\mathrm{z})$ kilometer blocks in the Red Mountain area based on reduced to the pole Earth's magnetic field data, Red Mountain area, southeastern Arizona. Data from Berger and others (2003). 


\section{Total Field Magnetic Data}

Total field magnetometers used in magnetic surveys of the Earth as discussed here measure the total intensity (without regard to direction) of the vector sum of the following: (1) the magnetic field generated internally by the Earth and approximated by the International Geomagnetic Reference Field (IGRF); (2) the diurnal or transient magnetic field generated by interaction of the internal magnetic field with solar wind; (3) the induced magnetic field generated by the interaction of the Earth's internal magnetic field and the magnetic susceptibility of the rock masses near the magnetometer; and (4) the natural remanent magnetism field component of rock masses near the magnetometer (Morris and others, 2007). The IGRF is known (International Geomagnetic Reference Field, 2010) and is usually removed from the acquired data by the contractor (as was case for the 1996 Patagonia aeromagnetic survey). Additionally, the contractor made the necessary transient magnetic field corrections based on a stationary magnetometer in the location of the survey during the acquisition of survey data. Because the Earth's internal field is dominant, the measured values are assumed to be in the Earth's field direction at the time of measurement. Induced magnetization is the component of magnetism in a material produced in response to an external applied magnetic field; it vanishes when the applied field is removed. Remanent magnetization is the permanent magnetization that remains in a material when the applied external field is removed and is essentially unaffected by weak magnetic fields (Clark, 1997). Neel (1955), supported by the work of Nicholls (1955) and Runcorn (1955), showed that for most rocks, especially those with thermoremanent magnetization, the remanent magnetization is stable over geologic time scales. The induced and remanent magnetic field properties of rock masses give rise to magnetic anomalies that are used for geologic interpretation. These anomalies are created by contrasts in magnetic susceptibility and remanence at contacts between adjacent rock masses of differing physical properties.

The magnetization of a rock mass, $\mathbf{J}$ (magnetic dipole moment per unit volume), is equal to the vector sum of the induced field, $\mathbf{J}_{\mathbf{i}}$, and the natural remanent magnetism field, $\mathbf{J}_{\mathrm{r}}$, that is, $\mathbf{J}=\mathbf{J}_{\mathrm{i}}+\mathbf{J}_{\mathrm{r}}$. For sufficiently weak fields, such as the Earth's magnetic field, the induced magnetization, $\mathbf{J}_{i}$, of a material is approximately proportional to and parallel to the applied field with the constant of proportionality known as the magnetic susceptibility, $k$ (Clark, 1997). Therefore, the magnetization component due to the susceptibility (SI) of rock mass is equal to $\mathbf{J}_{\mathrm{i}}=k \mathrm{~F}$, where $\mathrm{F}$ is the magnitude of the Earth's internal field in amperes per meter $(\mathrm{A} / \mathrm{m})$, and can be approximated by IGRF. Figure 6 shows susceptibilities for several types of rock lithologies.
The natural remanent magnetism vector, $\mathbf{J}_{\mathrm{r}}$, is a quasipermanent magnetization inherent in the rock mass and composed of primary and possibly secondary magnetizations (Butler, 1998). The primary remanent magnetization for igneous rocks is thermoremanent magnetization, acquired by cooling and solidification of an igneous rock from greater than the Curie temperature. For sedimentary rocks it is detrital remanence, produced by magnetic sediments (composed of minerals) aligning themselves with the Earth's magnetic field before being incorporated into a sedimentary rock. Secondary remanent magnetizations include chemical remanent magnetization, which records the magnetization of the Earth's field from the crystallization of minerals less than the Curie temperature, viscous remanent magnetization, which is acquired by ferromagnetic minerals after spending a great deal of time in a magnetic field with a stable orientation, and several generally less important components.

The Koenigsberger ratio, Q (Koenigsberger, 1938a and $1938 b$ ), is the ratio of the remanent magnetization to the induced magnetization for a rock mass, $\left|\mathbf{J}_{\mathrm{r}}\right| /\left|\mathbf{J}_{\mathrm{i}}\right|$. Figure 7 shows $Q$ values ranges for several types of rock lithologies. The total magnetization of a rock mass is the vector sum of $\mathbf{J}_{\mathrm{r}}$ and $\mathbf{J}_{\mathrm{i}}$ and the direction of $\mathbf{J}_{\mathrm{i}}$ is always approximated by the direction of the Earth's current magnetic field. The direction of $\mathbf{J}_{\mathbf{r}}$ is dependent on the direction of the Earth's magnetic field at the time the remanence was incorporated into the rock and any tectonic movement that the rock mass has experienced since recording the past Earth's field. If aligned near the present-day magnetic field, $\mathbf{J}_{\mathrm{r}}$ will increase the magnetization of the rock mass; if $\mathbf{J}_{\mathbf{r}}$ differs from the current alignment by more than 90 degrees it will lower the observed magnetization of the rock mass or possibly create a rock dominated by the remanent magnetization vector (if $Q>1$ ). If $\mathbf{J}_{\mathbf{r}}$ points 90 degrees from $\mathbf{J}_{\mathrm{i}}, \mathbf{J}_{\mathrm{r}}$ will not contribute to the measured magnetic field component in the Earth field direction. The natural remanent magnetism vector cannot have any possible orientation; rather the orientation must be compatible with the expected age of remanence acquisition (Morris and others, 2007) and with tectonic activity since that time.

For geologic anomalies, a total field magnetometer measures the intensity $|\mathbf{J}|=\left|\mathbf{J}_{\mathrm{i}}\right|+\left|\mathbf{J}_{\mathrm{r}}\right|$. If the susceptibility and remanence vector of a rock mass are both known, then the complete anomaly due to a rock mass can be defined. Generally, however, neither susceptibilities nor remanences are known. Susceptibility often is estimated by lithology from tables such as figure 6. Remanence is often ignored. Most of the total magnetic field interpretations of the Earth use only susceptibility, and few investigators have included magnetic remanence as a contributor to studies of continental magnetic anomalies (Morris and others, 2007). 


\section{IGNEOUS ROCKS}

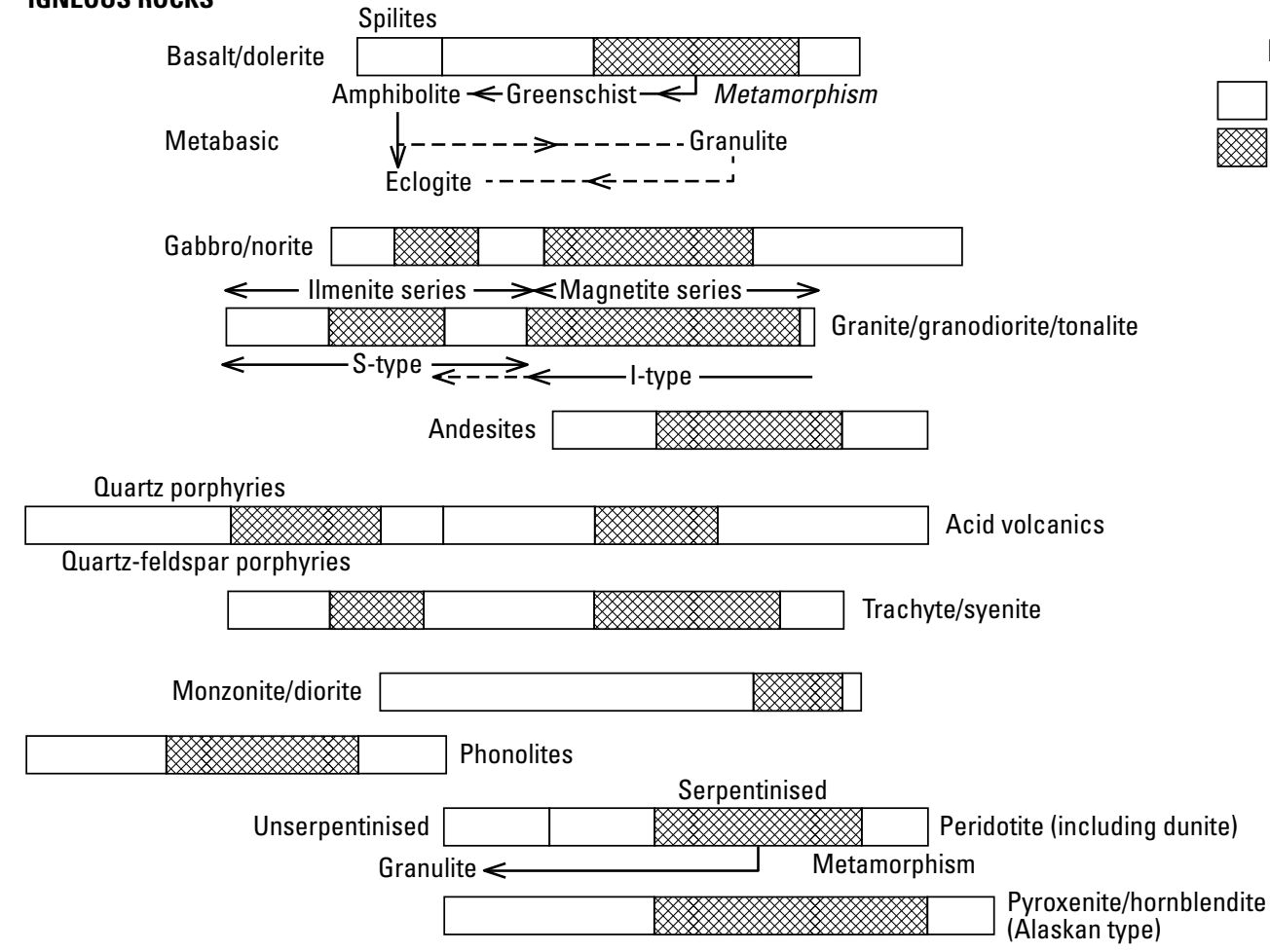

EXPLANATION

METAMORPHIC ROCKS

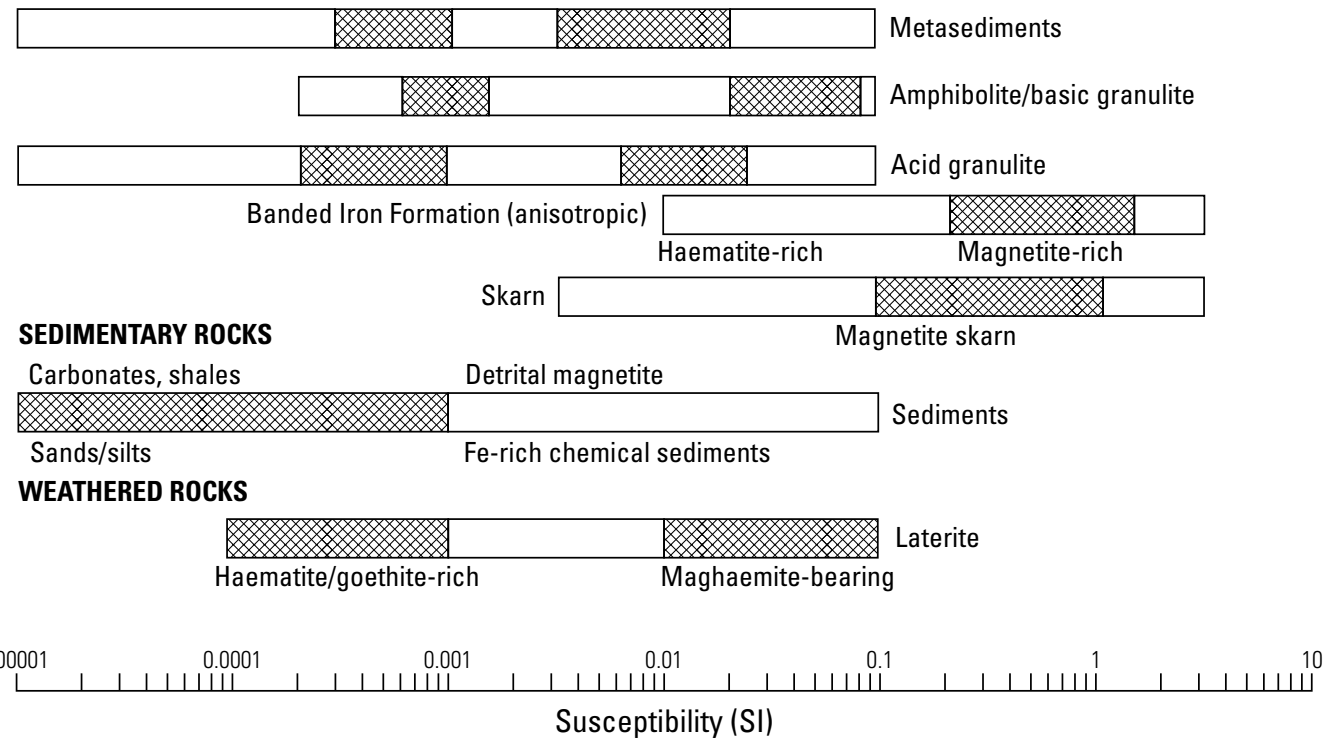

Figure 6. Susceptibility of common rocks (after Clark, 1997). Bar represents range, shaded area includes most rocks. 


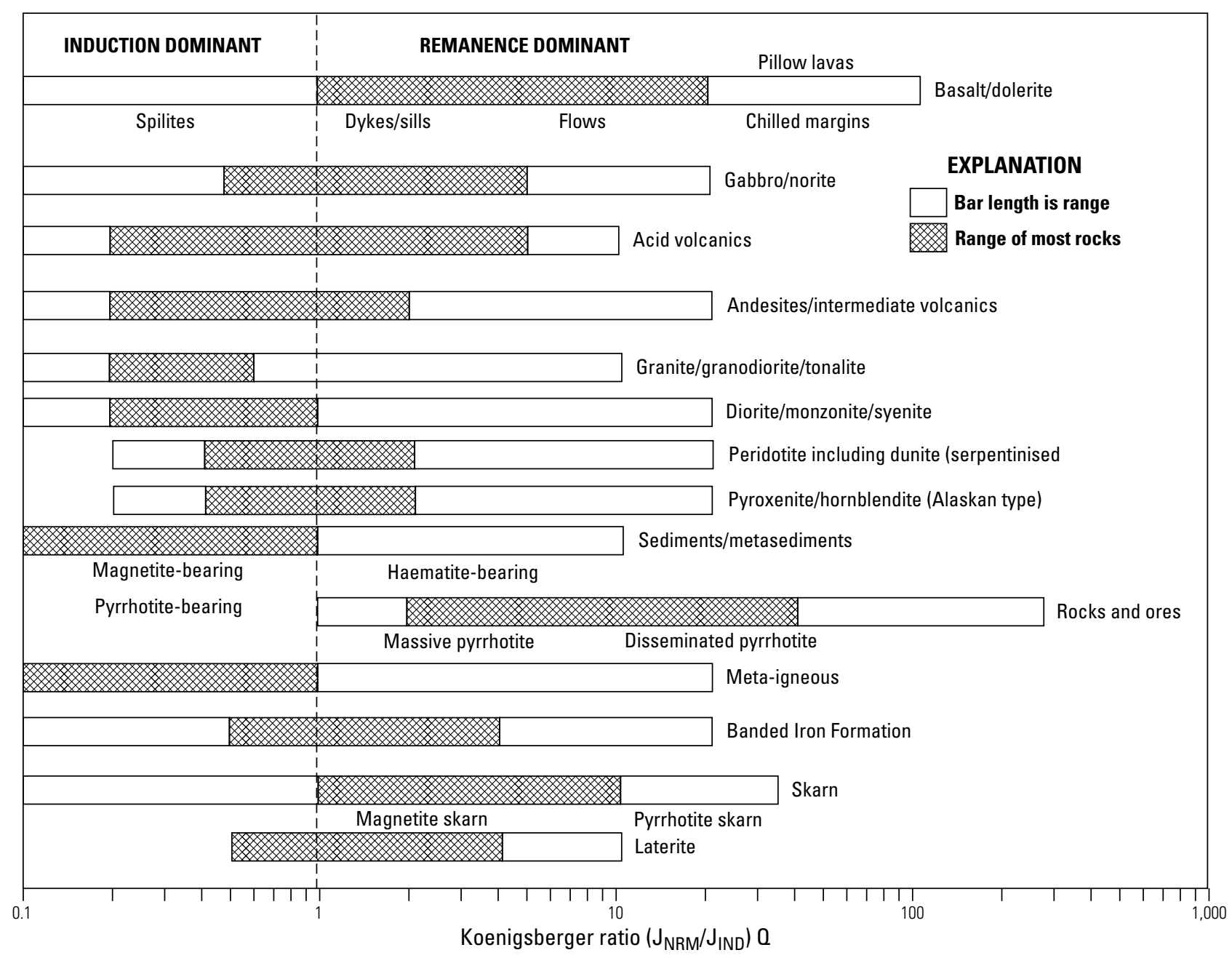

Figure 7. Koenigsberger ratio of common rocks (after Clark, 1997). Bar represents range, shaded area includes most rocks.

In this report, two terms are used to describe remanent magnetization directions in rocks (suggestion from Mark Gettings, U.S. Geological Survey, written commun., 2013). The first, enhanced total magnetic intensity remanence describes natural remanent magnetism that contributes or adds to the intensity of the induced field (fig. 8). These are remanent field directions that are between 0 to just less than 90 degrees from the direction of the current induced field. The second, reduced total magnetic intensity remanence describes natural remanent magnetism that reduces the intensity of the induced field (fig. 8). These remanent field directions are from slightly more than 90 degrees to 180 degrees from the direction of the induced field. Generally, rocks that have a reduced total magnetic intensity natural remanent magnetism inherited their remanent field when the Earth's magnetic field had a polarity opposite that of the current geomagnetic field. Some rocks with reduced total magnetic intensity natural remanent magnetism may have been rotated tectonically to a position where their remanent field vector is more than 90 degrees from the Earth's current magnetic field direction. 


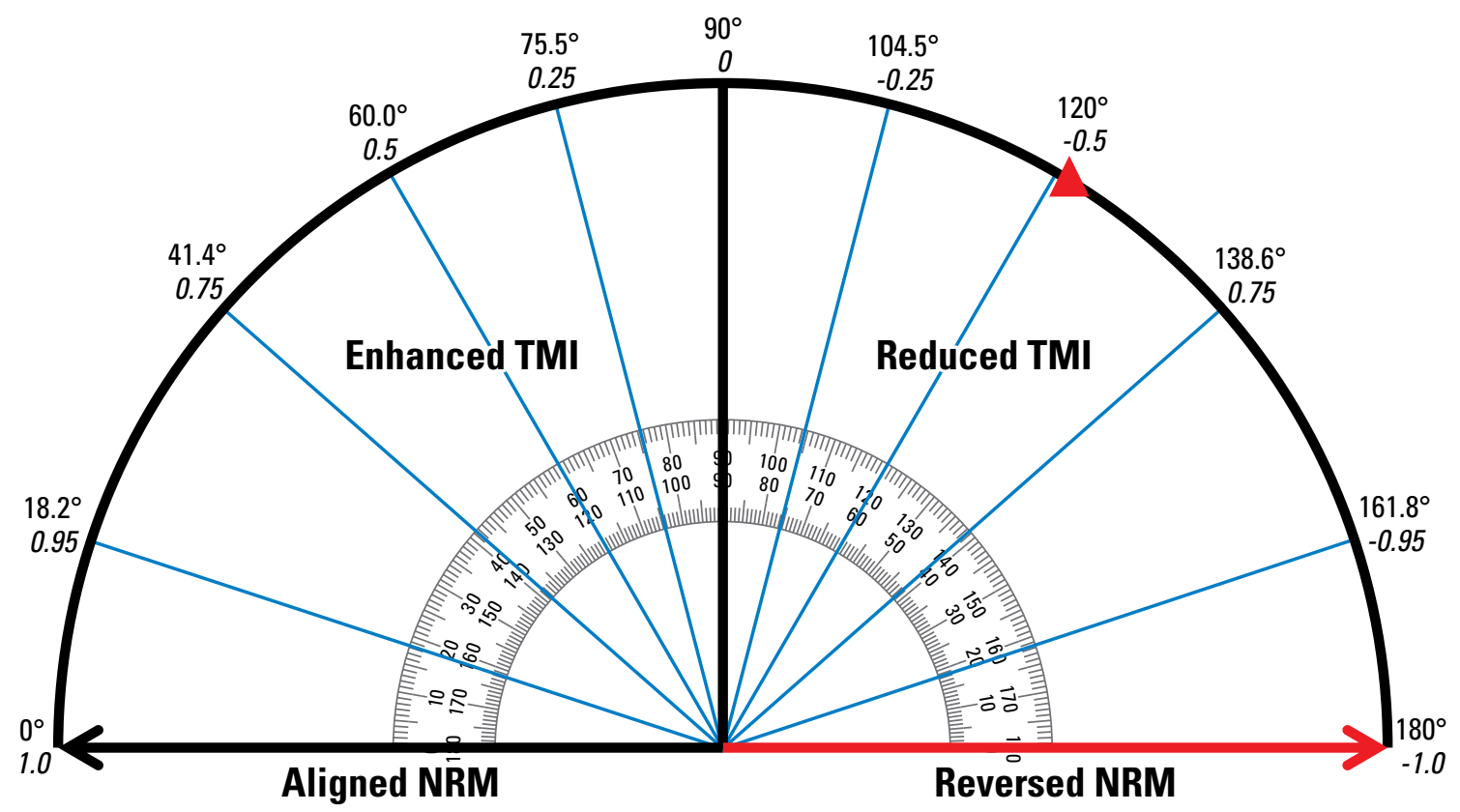

Figure 8. Contribution to the Earth's magnetic field total magnetic intensity (TMI) from the natural remanent magnetic (NRM) field based on the angle between the magnetic field (induced) and the NRM field. Angles between the two fields are labeled for contributions to the induced field of $1.0,0.95,0.75$, $0.5,0.25,0,-0.25,-0.5,-0.75,-0.95$, and -1.0 times the remanent intensity. The angle between the remanent field used for reduced TMI concealed intrusions in this report is 120.6 degrees (red triangle) which reduces the TMI by 0.51 times the NRM field intensity. Diagram created with suggestions from Mark Gettings (U.S. Geological Survey, written commun., 2013).

\section{Magnetic Susceptibility of Rock in the Patagonia Mountains Area}

Magnetic susceptibility (SI) measurements of outcropping rock were acquired at 45 sites in the Patagonia Mountains region and were published in Gettings and Bultman (2014). These data were acquired with a ZH Instruments SM-30 magnetic susceptibility meter. Outcrop susceptibility was estimated by making 7 to 20 readings taken at random locations with minimum spacing of approximately $20 \mathrm{~cm}$ on the outcrop face. The mean susceptibility is $0.0076 \mathrm{SI}$ and only one sample has a negative susceptibility. Six samples have susceptibilities greater than 0.02 SI. Figure 9 displays a histogram of the susceptibility data.

Paleomagnetic data for the Patagonia batholith were presented by Hagstrum (1994) and are presented in table 2. Samples were collected from Sycamore and Providencia Canyons (fig. 3) on the west central part of the stock and three sites (PG4, PG5, and PG6; table 2) showed the presence of reduced total magnetic intensity natural remanent magnetism (Hagstrum, 1994).

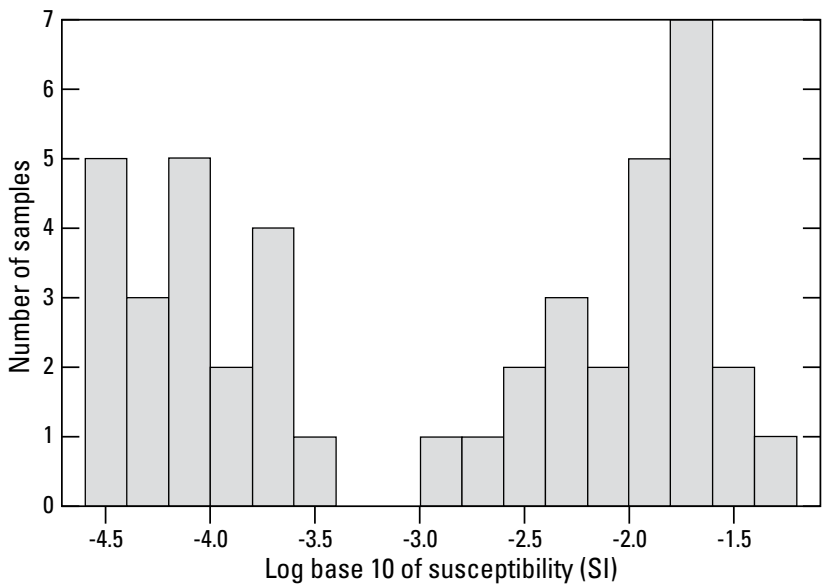

Figure 9. Histogram of the base 10 logarithm of susceptibility for samples from the Patagonia Mountains, southeastern Arizona. One sample with negative susceptibility was excluded. 
Table 2. Patagonia granodiorite remanent magnetization measurements, Patagonia Mountains study area, southeastern Arizona.

[After Hagstrum (1994)]

\begin{tabular}{lccc}
\hline Patagonia batholith & Inclination & Declination & $\begin{array}{c}\text { Number of } \\
\text { samples }\end{array}$ \\
\hline PG1 & 41.3 & 355.1 & 6 \\
PG2 & 54.4 & 334.9 & 8 \\
PG3 & 48.3 & 343.7 & 8 \\
PG4 & 52.5 & 343.9 & 7 \\
& -47 & 334.7 & 11 \\
PG5 & 47.3 & 329 & 2 \\
& -72.4 & 27.9 & 7 \\
PG6 & -62.3 & 14.4 & 9 \\
Average, PG1 through & 49.1 & 341.8 & 5 \\
$\quad$ PG4 & & & \\
\hline
\end{tabular}

\section{Measured Susceptibility, Remanence, and Geology Incorporated into Forward Magnetic Modeling}

Berger and others (2003), presented a geologic model of the region near Red Mountain (figs. 4 and 5) based on 506 vertical prisms $0.5(\mathrm{y}) \times 0.5(\mathrm{x}) \times 1.0(\mathrm{z}) \mathrm{km}$ in size. This simple model, in an area with exceedingly complex geology, produced results that relied on negative susceptibilities to reproduce the observed magnetic field. Eighteen measurements of rock susceptibility in the area of this geologic model produced no samples with negative susceptibility (Gettings and Bultman, 2014).

Geologic information was incorporated into new modeling using measured magnetic susceptibilities (Gettings and Bultman, 2014), estimated natural remanent magnetism based on lithology, magnetic field strength and direction of the Earth, estimated Koenigsberger ratios, measured remanence directions based on Hagstrum (1994), geologic mapping (Simons, 1974; Drewes, 1980; 1996; Drewes and others, 2002), and succession of events that led to the formation of the Patagonia batholith (Vikre and others, 2009). By incorporating known geology and measured physical properties of rock in the region into the model, a new geologic model was produced that is strikingly different from the model produced by Berger and others (2003).

Two-dimensional forward modeling was accomplished with the GM-SYS modeling package in Oasis Montaj (Geosoft, 2013). GM-SYS allows the inclusion of remanent magnetism if the remanent intensity, inclination, and declination are known. When possible, both enhanced and reduced total magnetic intensity natural remanent magnetizations were included in the geologic modeling of the Patagonia Mountains study area.
Based on Hagstrum (1994) the Patagonia batholith (map unit Tlg; table 1, fig. 3) has a natural remanent magnetic field with an average inclination of 49.1 degrees and declination of 341.8 degrees based on the data from five samples collected from the west side of the batholith (table 2). Additionally, three samples collected from that general area and within the batholith show a natural remanent magnetism direction quite different from the current induced field direction (those with negative inclinations, table 2). A main component of the new modeling presented here suggests the existence of a late concealed stock emplaced at the northern end of the Patagonia Mountains region that corresponds with a low in the aeromagnetic anomaly map (fig. 4). One of the natural remanent magnetic field samples, PG6 (Hagstrum, 1994, table 2), was selected to represent the reduced total intensity natural remanent magnetic field in the study area at the time of the emplacement of the concealed stock. The natural remanent magnetic field direction of PG6 is 120.6 degrees from the current magnetic field of the Earth (fig. 10). Vikre and others (2009) have shown the main large volume emplacement of the Patagonia batholith is associated with the $60 \mathrm{Ma} \mathrm{Cu}-\mathrm{Mo}$ breccia deposit at Red Hill (Four Metals Mine, fig. 2) in the southern part of the pluton. The estimated emplacement of the northern concealed stock is $61-58 \mathrm{Ma}$ (Vikre and others, 2009); therefore, the natural remanent magnetism vector direction for this stock is plausible.

Remanent intensities were estimated by using $Q$ values for specific lithologies based on figure 7 (Clark, 1997) and on the relation $\mathbf{J}_{\mathrm{r}}=\mathbf{J}_{\mathrm{i}} \times \mathrm{Q}=k \times \mathrm{F} \times \mathrm{Q}$. At the time of the survey, $\mathrm{F}=38.41 \mathrm{~A} / \mathrm{m}$. For example, map unit Tlg (Drewes and others, 2002), has measured $k=0.0200$ SI (table 1). Based on the lithology of map unit Tlg (granodiorite to quartz monzonite, table 1) the estimated Koenigsberger ratio (Qe) for this composition of rock varies from 0.1 to 10 with most values ranging from 0.2 to 0.6 (fig. 7). Qe was selected to be 0.6 because the composition of map unit $\mathrm{Tg}$ is on the more mafic end of the rock compositions used in figure 6 . This gives an estimated remanent intensity of $\mathbf{J}_{\mathbf{r}}$ as $0.46 \mathrm{~A} / \mathrm{m}$. Other remanent intensities were calculated in a similar fashion and are given in table 1.

Two intrusive units that are entirely concealed are hypothesized here and used in the modeling. Their existence is required to fit forward magnetic models of the geology to the aeromagnetic data when measured rock physical properties are used in the models. The intrusive rocks are late stages in the emplacement of the Patagonia batholith, during the fifth and sixth events of the succession of events defined by Vikre and others (2009). Their composition is estimated to be the same as the composition of the Patagonia batholith, diorite to quartz monzonite. The estimated susceptibility and remanent intensity for these concealed intrusive rocks was based on that composition and data from figures 6 and 7 . 


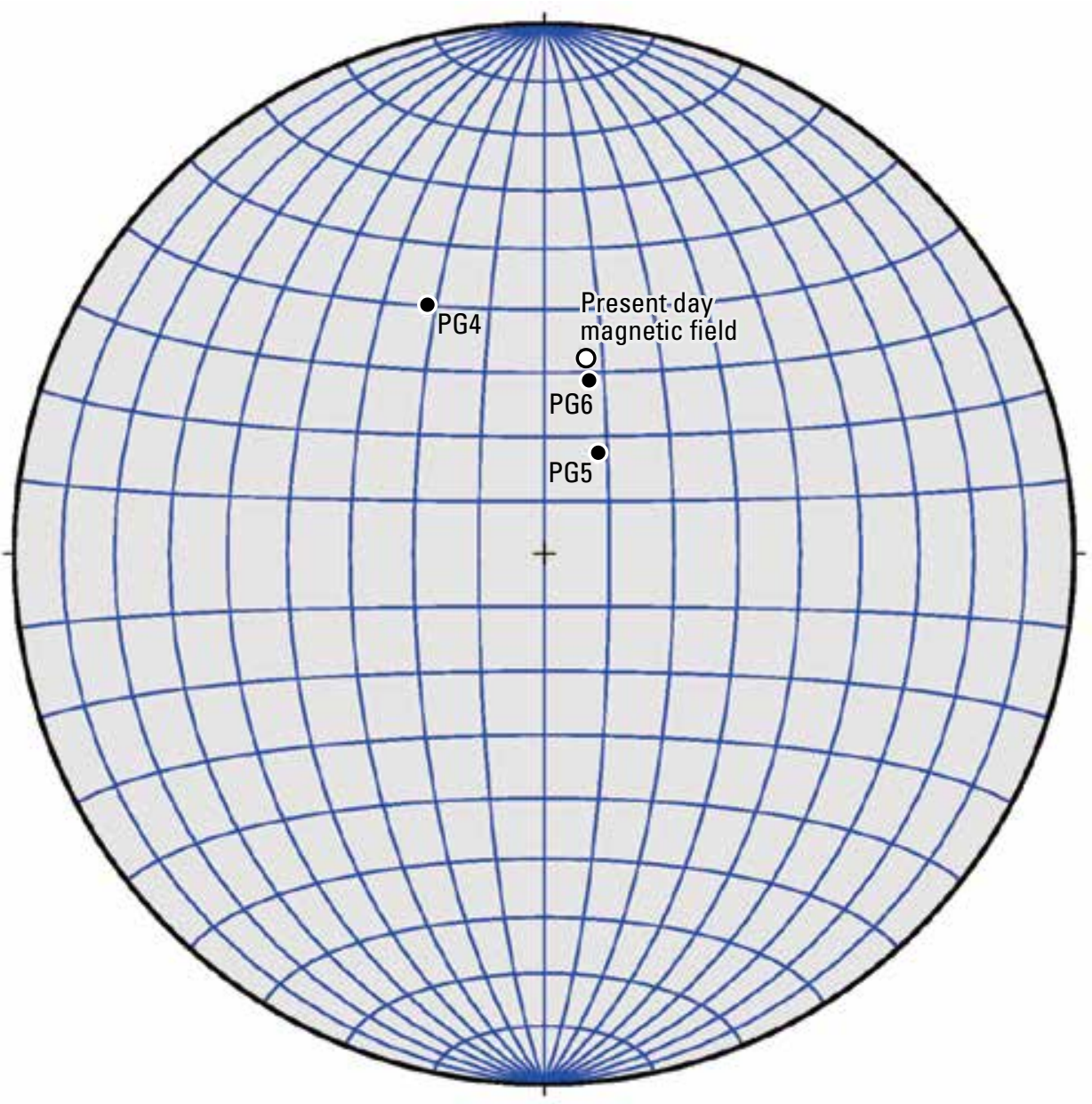

Figure 10. Stereonet plot of samples collected from the Patagonia batholith with reduced total magnetic intensity natural remanent magnetic field (table 2) and the present-day inductive field of the Earth, Patagonia Mountains study area, southeastern Arizona. Solid symbols indicate projection from the upper hemisphere and open symbols indicate projection from the lower hemisphere. The natural remanent magnetic field for hypothetical intrusions with reduced total magnetic intensity natural remanent magnetic field in this report (map unit Tgr, table 1) uses sample PG6, which is 120.6 degrees from the current (2014) magnetic field in the Patagonia Mountains. 


\section{Geologic Model}

Geologic modeling was based on the aeromagnetic survey flight-line data whose locations are displayed in figures 3 and 4. Modeling began by placing all the data from the survey flight lines into GM-SYS and adding all contacts in the proper locations at the surface of the model (fig. 3; Drewes, 1980; Drewes and others, 2002). Map units (column 2, table 1) used for modeling were based on Drewes (1980) and Drewes and others (2002). Average magnetic susceptibilities as measured in the field (or from the literature as cited in table 1) were assigned to each map unit lithology and remanent magnetisms were estimated for lithologies with susceptibility greater than 0.02 SI. Adding remanence to map units with susceptibilities less than 0.02 did not significantly affect the model in this study. Two concealed intrusive rocks were inserted at depth to allow the model to fit the data. Then model geologic boundaries were moved until the model achieved a reasonable geology and a forward magnetic model (black lines, figs. 11 and 12) that matched the measured magnetic anomaly (black dots, figs. 11 and 12). The model results are shown in figures 11 and 12.
Profile 1, a south to north profile of the Patagonia Mountains is shown in figure 11 (figs. 3 and 4 show profile location). This profile contains mostly outcropping bedrock with measured susceptibilities and is therefore very constrained. Colors for map units in the geologic model were selected to be similar to those used in the geologic map shown in figure 3. Precambrian granite (Yg; fig. 11, table 1) outcrops on the south end of the profile and likely is underlain by Jurassic granite (Jg; fig. 11, table 1), which surrounds it at the surface. Using measured susceptibilities and remanent intensities calculated from estimated Q values (table 1, fig. 7), it was not possible to obtain the adjacent high and low anomaly values seen in profile 1 (fig. 11) at kms 8.5 and 14 without introducing a high susceptibility concealed intrusive (map unit Tgc, table 1) and an intrusive with reduced total magnetic intensity natural remanent magnetism (map unit Tgr, table 1) into the model. Map unit Tgc is assumed to be of a similar composition to Tlg (table 1) but was assigned a higher susceptibility (and therefore remanence) than Tlg to produce the aeromagnetic high at the $\mathrm{km} 9$ mark of the profile. Based on figures 6 and 7 map unit Tgc was arbitrarily assigned $k=0.05(\mathrm{SI})$ and $\mathrm{Qe}=0.6$; therefore, the intensity of $\mathbf{J}_{\mathrm{r}}=1.15 \mathrm{~A} / \mathrm{m}$. These values of SI and Q are well within the

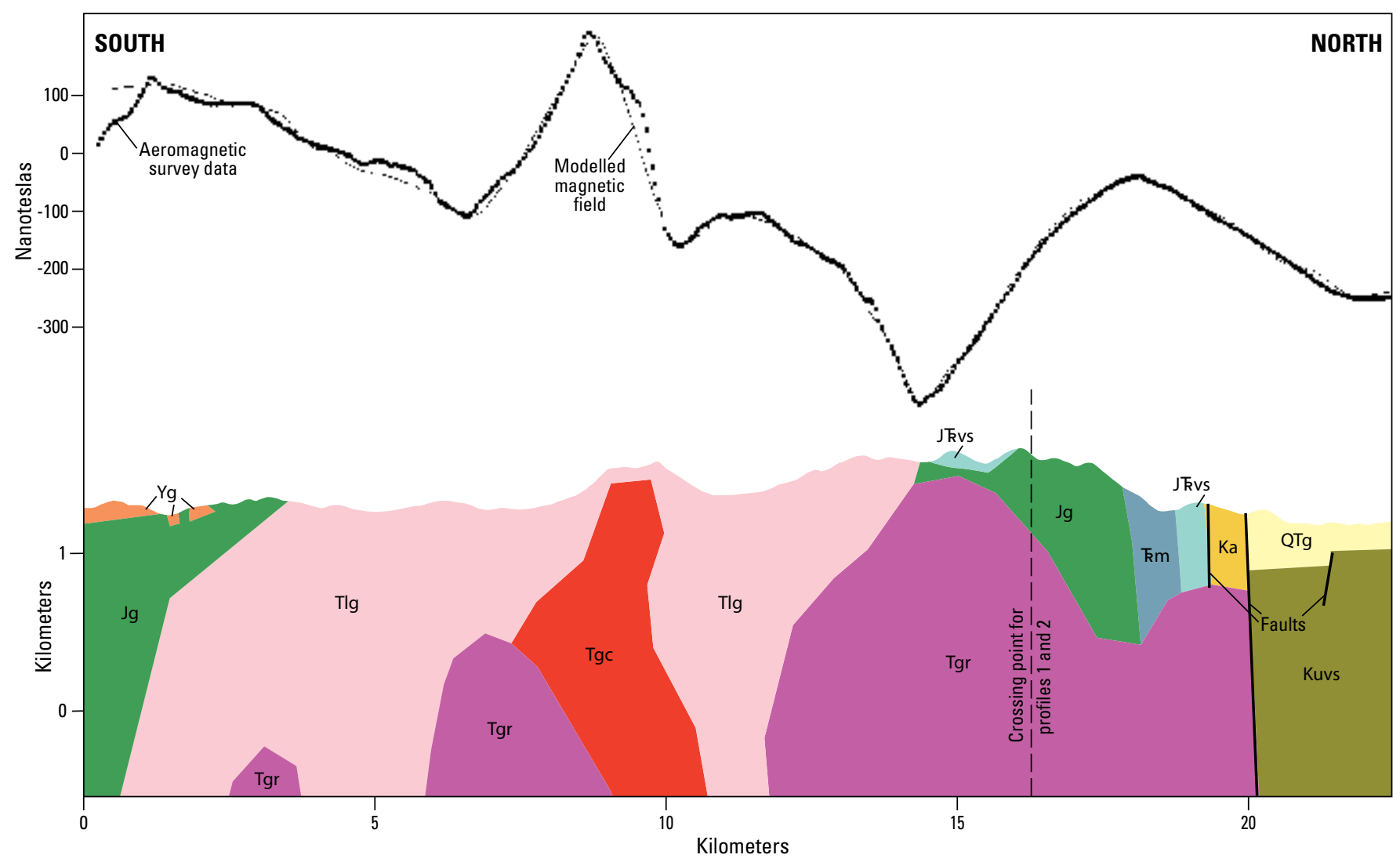

Figure 11. Geologic cross section for profile 1, Patagonia Mountains study area, southeastern Arizona. Profile locations are shown in figures 3 and 4. Black dots, aeromagnetic survey line data; black line, model results. Hypothesized concealed intrusions are labeled as map units Tgr and Tgc. Map unit labels are shown in table 1. 
range of values that are in rocks of diorite to quartz monzonite composition (figs. 6 and 7). Map unit Tgc is assumed to be an apophysis of very late stage intrusion in the emplacement of the main body of the Patagonia batholith and may be related to outgassing and mineral deposits (for example, Four Metals mine) formed near Red Hill (fig. 2; Vikre and others, 2009).

The aeromagnetic anomaly low at $\mathrm{km} 14$ in the profile 1 (fig. 11) could not be modeled without including a concealed intrusive having a reduced total magnetic intensity remanence, map unit Tgr (table 1). This intrusive, the last phase of the formation of the Patagonia batholith may be responsible for the Sunnyside porphyry copper deposit that lies just $1 \mathrm{~km}$ to the east of this profile at the location of the lowest anomaly value, near km 14. Although the exact age of this concealed body is not known, there are large periods of reversed magnetic field polarity that occurred during its formation (61$58 \mathrm{Ma}$, Vikre and others, 2009) associated with chrons 27 and 26 (Butler, 1998). This intrusive is therefore given a reduced total magnetic intensity natural remanent magnetic field with a direction estimated from the Patagonia batholith $(\sim 62$ Ma) sample PG6 (table 2; Hagstrum, 1994) and a remanent intensity estimated from figures 6 and 7 (table 1).
The Patagonia Fault is located at $\mathrm{km} 20$ in the profile, and the Sonoita Basin lies to the north of the fault. Betts and others (1998) used electromagnetic data to model the Sonoita Basin and determined that it contained about $200 \mathrm{~m}$ of basin fill just north of the Patagonia Fault where Alum Gulch enters the Sonoita Basin (fig. 2), near the location of profile 1. The model displayed in profile 1 also shows about $200 \mathrm{~m}$ of basin fill at this location. Volcanic rocks (Kuvs; table 1) with a relatively high SI (0.02), a high Q (1.4), and a low total magnetic intensity natural remanent magnetic field (table 1 ) underlie the basin fill. This concealed volcanic unit could be map unit Jg (table 1), which is exposed to the north of the basin as the Squaw Gulch volcanic rocks (Gettings, 2002) and has reduced total magnetic intensity natural remanent magnetism. Based on the aeromagnetic anomaly low shown in figure 4, map unit Kuvs in this location extends to the southwest to an easting of 519000 and to the northeast to the edge of the Red Mountain block. A reduced total magnetic intensity natural remanent magnetic field is required for this map unit in order that the magnetic model to fit the aeromagnetic data. Map unit Kuvs may be related to Cretaceous "Bathtub" volcanic rocks mapped just to the north of this profile, at least some of which

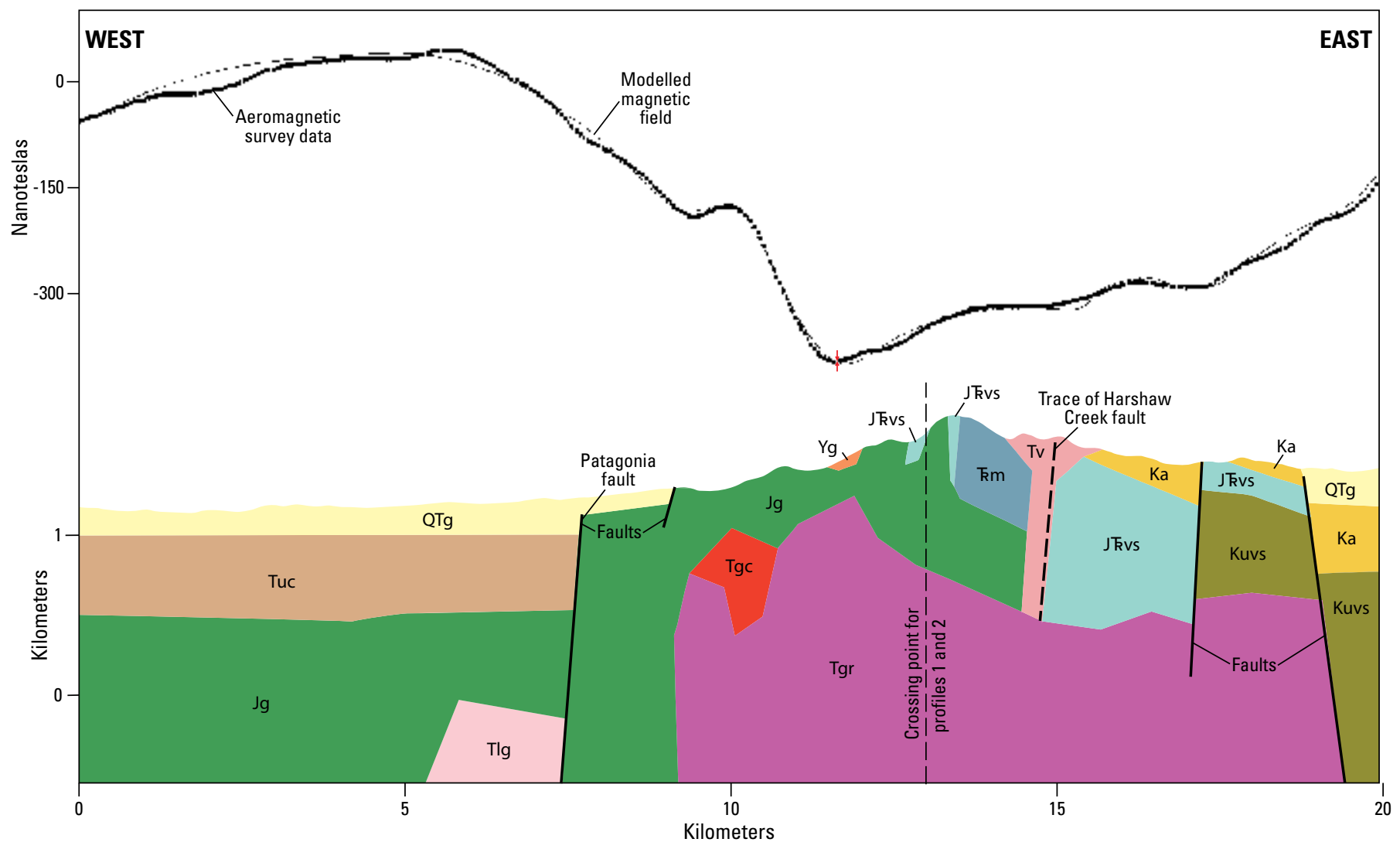

Figure 12. Geologic cross section for profile 2, Patagonia Mountains study area, southeastern Arizona. Profile locations are shown in figures 3 and 4. Black dots, aeromagnetic survey line data; black line, model results. Hypothesized concealed intrusions are labeled as map units Tgr and Tgc. Map unit labels are shown in table 1. 
are known to have a reduced total magnetic intensity natural remanent magnetic field (Gettings, 2002). The inclination and direction of that remanent field was selected to coincide with sample PG 6 (table 2; Hagstrum, 1994). All physical properties of map unit Kuvs are estimated and the exact structural relations, especially depth, could vary based on the selection of those physical properties. If the assumptions made here are valid, it may show, as suggested by Gettings and Gettings (1996) for the Tombstone area, that some Cenozoic basins in Arizona with large aeromagnetic anomaly lows may contain relatively shallow basin fill underlain by volcanic or intrusive rocks with nonaligned remanent magnetic fields and not thick accumulations of low susceptibility sediments. This could have significant water resources implications. When models are used in basins with aeromagnetic data, it is important to simulate adjacent ranges also to determine if the low values in basins can be accurately simulated when lithologies of known susceptibility are included in the model in the ranges.

Figure 12 displays an east to west geologic model along profile 2 (figs. 3 and 4). As in figure 11, the dotted black line on top of the cross section is the aeromagnetic data, the thick black line is the aeromagnetic anomaly produced by the forward model due to the geology in the cross section. This model was started at the crossing point of the two models where Jurassic granite (Jg, table 1; fig. 12) is exposed at the surface and a hypothesized concealed Tertiary granite with reduced total magnetic intensity natural remanent magnetism (Tgr, table 1) is found at depth. The concealed granite was initially given the same depth on both profiles at this location (about $600 \mathrm{~m}$ ). The final model in figure 12 has the body deeper, about $800 \mathrm{~m}$, but the contact is dipping steeply at this location. Concealed lithologies under map units Tuc and QTg (table 1) in the western part of the model are based on Simons (1974), Drewes (1980), and Drewes and others (2002). A concealed intrusive unit (Tg; table 1) was required at depth at $\mathrm{km} \mathrm{5-7} \mathrm{in} \mathrm{the} \mathrm{profile} \mathrm{to} \mathrm{create} \mathrm{the} \mathrm{aeromagnetic} \mathrm{anomaly} \mathrm{high}$ that occurs between kms 5 and 7 in the profile (fig. 12).

The concealed Tertiary granite with reduced total magnetic intensity natural remanent magnetism, map unit Tgr (table 1) plays a large role in modeling the aeromagnetic profile data of figure 12 . The profile is dominated by a major magnetic low anomaly centered at $\mathrm{km} 12$ and this anomaly is part of the same low seen at $\mathrm{km} 14$ in figure 11. As in the model for profile 1 (fig. 11), this anomaly could only be modeled correctly by using a lithology with a reduced total magnetic intensity natural remanent magnetic field. Profile 2 directly crosses the Sunnyside porphyry copper deposit, near the km 14.5 mark. Although the Harshaw Creek Fault at this location is shown as concealed by a Tertiary flow by both Simons (1974) and Drewes (1980), field evidence indicates this is not a flow but an extrusive vent that may be associated with the emplacement of the main Patagonia batholith (Tlg; table 1), or an earlier intrusive in this area. The eruptive event may have followed the fault, which is known to be at least Jurassic in age. This volcanic neck (Tv, fig. 12 and table 1) cannot be modeled with a reduced total magnetic intensity remanent magnetic field, so is not directly related to Tgr (table 1). However, it may be associated with some earlier phase of the intrusion here and with the Sunnyside porphyry copper deposit. Moving farther east, there is a mapped fault separating map units Ka and JKvs at the surface with the hanging wall on the west side. Near $\mathrm{km} 19$, a modeled range bounding fault drops the bedrock to basin depths.

The model cross sections displayed in figures 11 and 12 indicate that the large aeromagnetic low to the south of Red Mountain (figs. 2 and 5) can be simulated only by incorporating a concealed intrusive body with a reduced total magnetic intensity natural remanent magnetic field at that location in the model. This intrusive is coincident in timing and location with the sixth and last event in Vikre and others (2009) succession of events that formed the composite Patagonia batholith. It is also coincident with the Sunnyside porphyry copper deposit, at least in location, but the extrusive event located structurally above map unit Tgr, map unit Jg, cannot possess a reduced total magnetic intensity natural remanent magnetic field and be accurately simulated. The approximate location of this concealed intrusive can be seen in figure 4 superimposed on the aeromagnetic data with a thick yellow line. It is truncated to the northwest and east by basin bounding faults. Additionally, the bedrock in the Sonoita Basin along Sonoita Creek (fig. 2) at the northern end of profile 1 (fig. 11) can be simulated as volcanic rock with a reduced total magnetic intensity natural remanent magnetic field concealed by relatively shallow basin fill.

\section{Complete Bouguer Anomaly Map}

The complete Bouguer anomaly map (fig. 13) of the northern part of the study area is based on data from Gettings and Houser (2000). The white crosses on the map indicate the locations of gravity stations from which the map was made. Figure 13 does not have a sufficient density of gravity stations, especially in the area of the hypothesized concealed intrusive (yellow line, fig. 13), to be used for the model. Although a distinct gravity high is associated with the proposed concealed intrusive, especially on the southeast side, it is controlled by only a few gravity stations. The model cannot conclusively prove or disprove the existence of this proposed intrusive body. This gravity anomaly does indicate that map unit Tgr may be cut off to the east and to the north by faults as was proposed in by the model simulations and that the proposed intrusive may extend slightly farther to the northeast than indicated by the magnetic anomaly data in figure 4 . This supposition is based on the small number of gravity stations. 


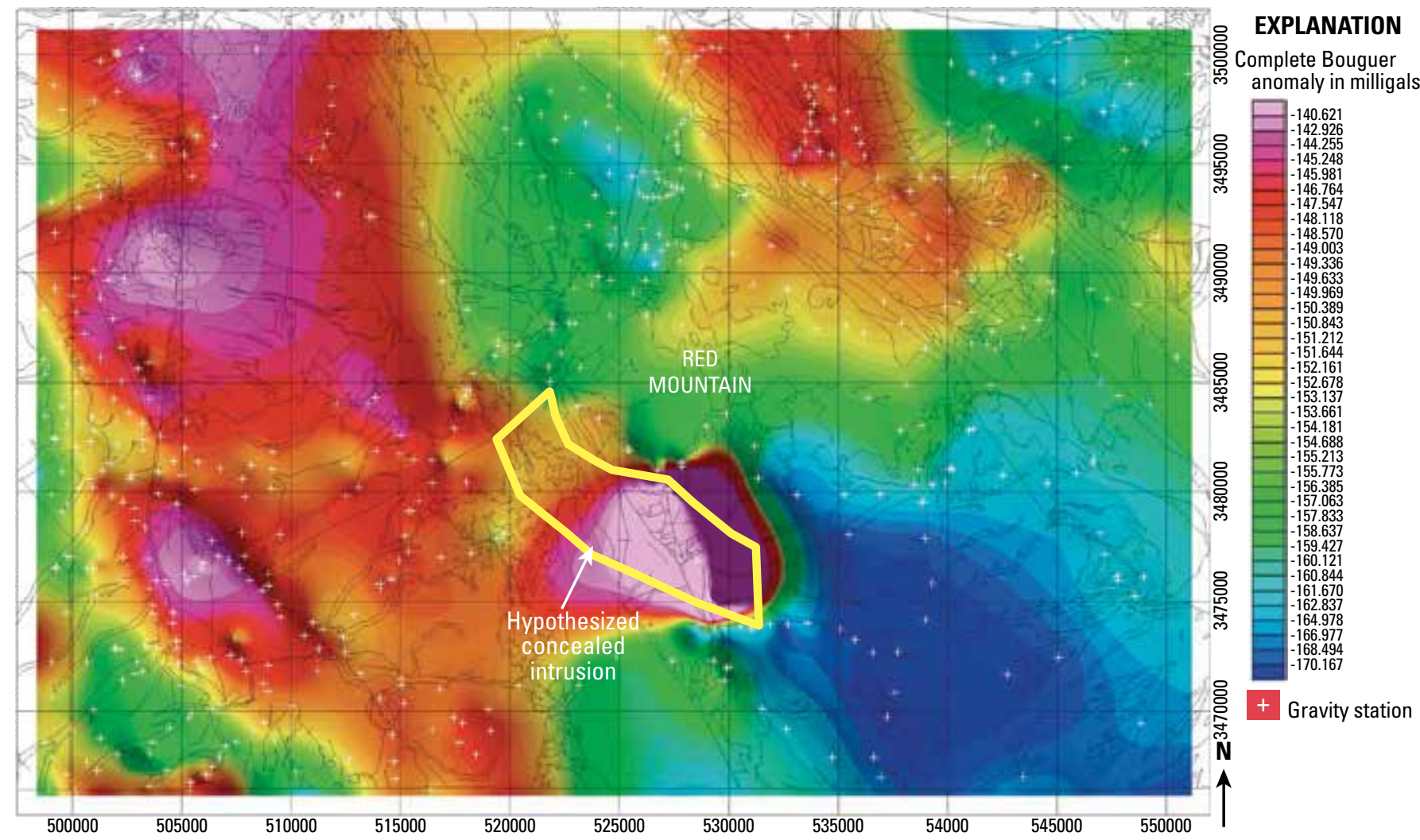

Figure 13. Complete Bouguer anomaly map of the northern part of the Patagonia Mountains study area, southeastern Arizona. Overlain geologic linework (black lines) from Drewes and others (2002).

\section{Euler Deconvolution Depth Estimates}

Euler's inhomogeneity equation can be used for making depth estimates with Earth's total field magnetic data (Yaghoobian and Boustead, 1993). This technique has numerous advantages over other types of depth estimates because no particular geological model is assumed, and it is not sensitive to magnetic inclination, declination, and remanence because these become a part of the constant in the anomaly function of a given model (Yaghoobian and Boustead 1993; Hsu 2002). Although the method can yield rather inaccurate estimates of depth (Casto, 2001), it still gives an approximation of anomaly depth and is ideal for estimating the spatial locations of the sources of observed anomalies. Depth estimates using the Euler equation are dependent on a scaling exponent selected at the start of the analysis. These scaling exponents are called structural indices and relate the distance dependence of the magnetic field to the shape of a geologic feature.
Depth estimates were obtained using Euler deconvolution in the Oasis Montaj program (Geosoft, 2013). Estimates for a structural index of 0 , which locates depth solutions for contacts and steps are shown in figure 14. The Euler deconvolution package in Oasis Montaj (Geosoft, 2013) allows the user to adjust several parameters including window size, depth tolerance, and distance. All settings were adjusted to allow for numerous solutions in order to produce a large number of depth estimates. The estimates that form linear patterns are used to identifying linear and elongate features in the data. The Patagonia Fault is clearly visible and labeled in figure 14. In the northeast part of the study area, the fault separates the Red Mountain block from volcanic rocks modeled with a reduced total magnetic intensity natural remanent magnetic field and concealed by basin fill to the northwest. Most of the depth estimates were about $200 \mathrm{~m}$ on the northeast part of the fault, which agrees with the depth of the volcanic rock in the Sonoita Basin northwest of the northeast striking Patagonia Fault presented in figure 12 and 

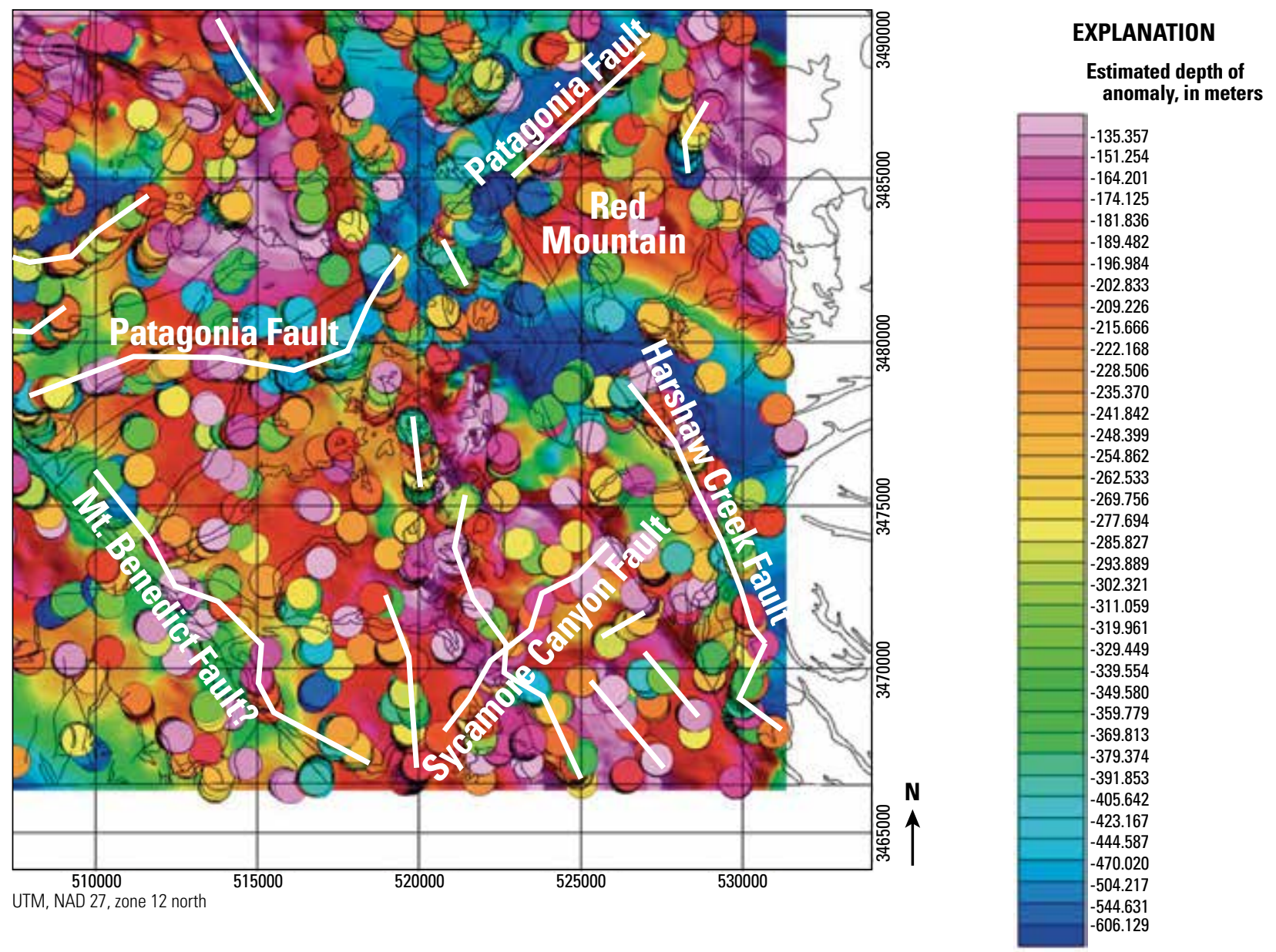

Figure 14. Euler deconvolution depth estimates (circles) for a structural index of 0 plotted over aeromagnetic data in the Patagonia Mountains study area, southeastern Arizona. Overlain geologic line work (black lines) from Drewes and others (2002).

reported in Betts and others (1998). To the southwest, the fault becomes obscured by intrusive rocks near Red Mountain and is lost in rocks with a reduced total magnetic intensity natural remanent magnetic field west of Red Mountain. Farther southwest, it deepens, then shallows and crosses from the south to north side of the Sonoita Basin. This had been unrecognized previously. The Harshaw Creek Fault is clearly visible on the eastern side of the cross section (fig. 12). It is truncated to the north where it meets low aeromagnetic anomaly values due to the proposed intrusion with reduced total magnetic intensity natural remanent magnetism. To the south, the fault shows a sharp kink just before the southeast edge of the map (fig. 14). The Guajolote Fault (fig. 2) is not visible in data shown in figure 14, but an unmapped northwest to southeast fault, which appears to be the western margin of the Patagonia batholith is clearly visible and intersects the
Sycamore Canyon Fault, which is visible. Several faults or contacts are visible in the Patagonia batholith, which might differentiate rock of slightly different composition or be related to intrusive sub-bodies within the stock. The concealed fault along the Santa Cruz River Valley (southwest corner of figure 14) is displaced to the east of its mapped location in this model. Several other concealed faults also can be seen in the west area of figure 14 .

A structural index of 1 displays depth solutions derived from the edges of sills and dikes and other bodies that are 1 plus dimensional and depth estimates for these features are shown in figure 15 . The faults examined in figure 14 are much less visible in figure 15 but the Guajolote Fault is visible. This may indicate that thick alteration or shear zones are associated with the fault. Few other linear features are visible in figure 15. 

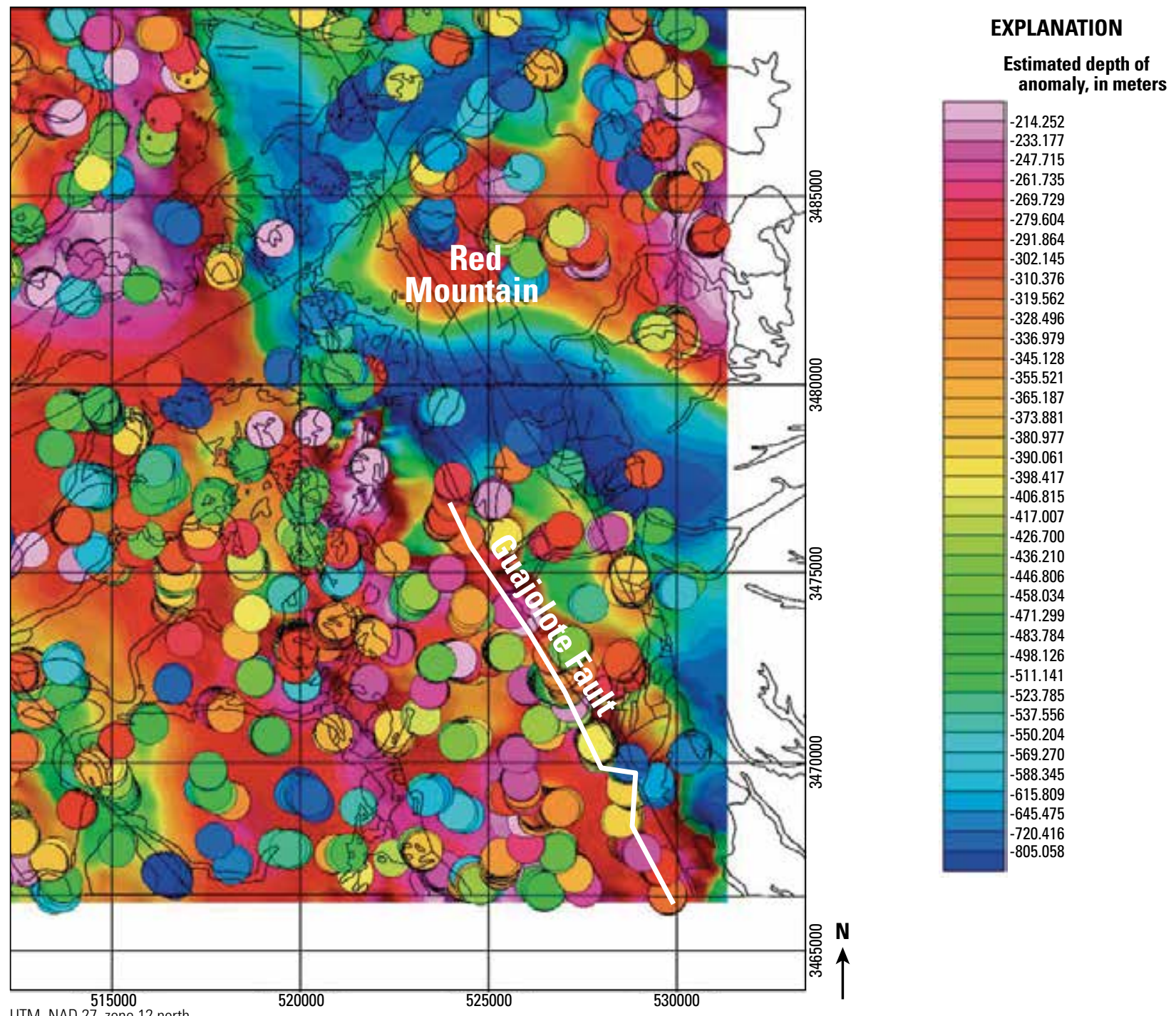

UTM, NAD 27, zone 12 north

Figure 15. Euler deconvolution depth estimates (circles) for a structural index of 1 plotted over aeromagnetic data in the Patagonia Mountains study area, southeastern Arizona. Overlain geologic line work (black lines) from Drewes and others (2002).

Euler depth estimates with a structural index of 2 produce solutions that are depth estimates of cylinder and pipe shaped sources. These sources are often indicated when a several depth estimates are stacked nearly on top of each other, which may be due to an apophysis or cupola of an intrusive body. Several types of solutions shown in figure 16 include: (1) porphyritic intrusive of Red Mountain at a depth of more than $400 \mathrm{~m}$; (2) possible intrusive near Lead Queen Mine (fig. 2); (3) possible intrusive near U.S. Mine (fig. 2); (4) possible intrusive that may be associated with the Washington Camp (fig. 2) and Duquesne mineral districts (south of area shown in figure 2); (5) possible intrusive that may be associated with Morning Glory Mine (fig. 2); (6) possible intrusive associated with Santo Nino Mine (south of area shown in figure 2); and (7) possible intrusive associated with Four Metals Mine, which may be related to map unit Tgc (figs. 2 and 11). Several potential intrusive rocks can be seen west of the Patagonia batholith (map unit Tlg; fig. 3). Euler depth estimates with a structural index of 3 display depths of spheres and barrel shaped sources. The depth estimate map produced for a structural index of 3 was nearly identical to figure 16 . 


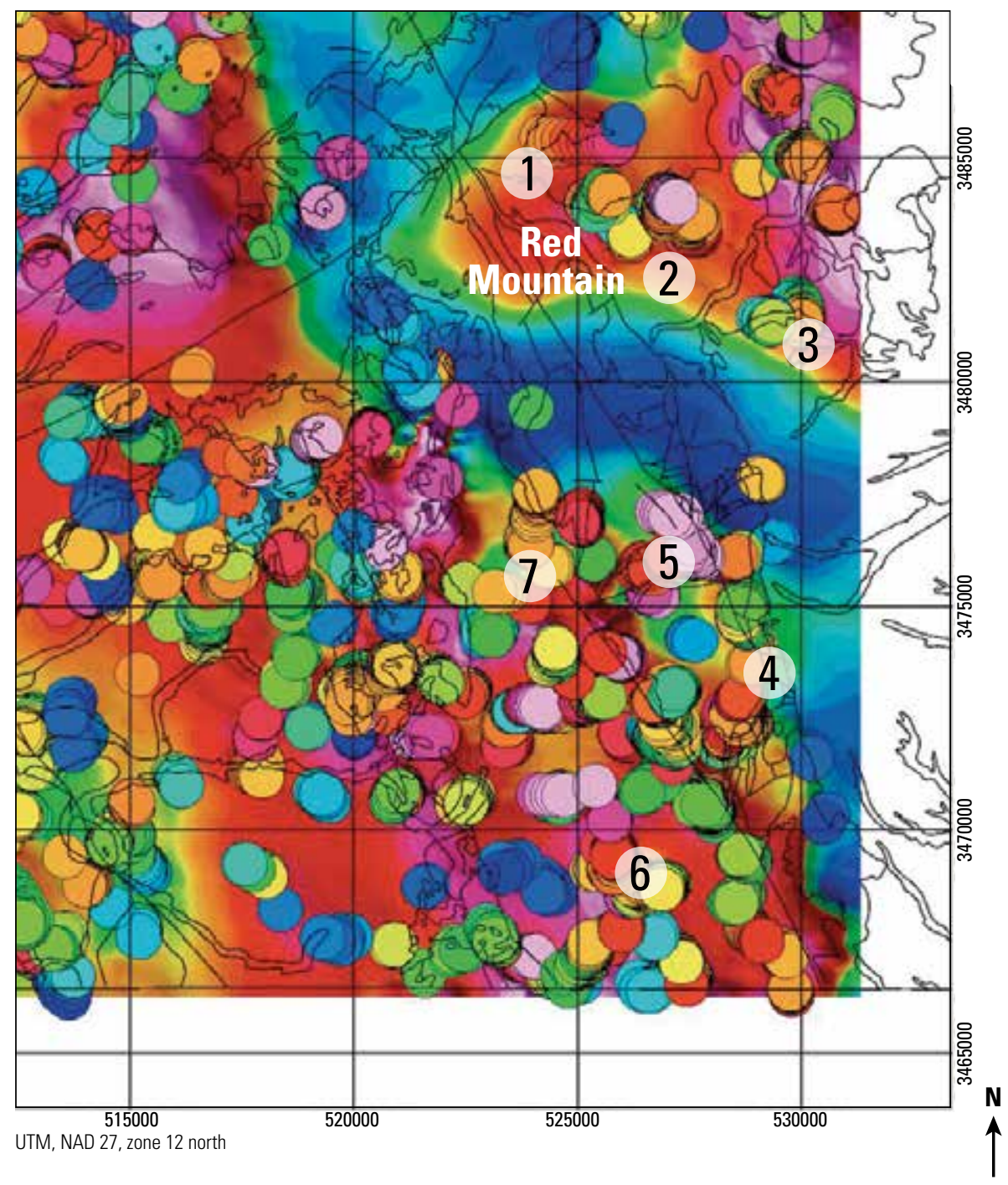

EXPLANATION

Estimated depth of anomaly, in meters

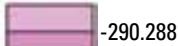

\begin{tabular}{|l|}
\hline-290.288 \\
\hline-315.792 \\
\hline
\end{tabular} -315.792
-342.202 $-358.981$

$-373.340$

$-386.959$

$-403.507$

$-416.153$

$-427.640$

$-436.463$

$-445.053$

$-456.403$

$-466.789$

$-476.091$

$-486.682$

$-496.575$

$-505.926$

$-516.518$

$-528.327$

-540.375
-551.283

$-563.220$

$-575.001$

$-587.289$

$-601.870$

$-617.548$

$-631.603$

$-647.273$

$-663.080$

$-680.063$

$-696.833$

$-713.800$

$-734.418$

$-757.010$

$-785.616$

$-811.706$

$-843.580$

$-885.303$

Figure 16. Euler deconvolution depth estimates (circles) for a structural index of 2 plotted over aeromagnetic data in the Patagonia Mountains study area, southeastern Arizona. Overlain geologic line work (black lines) from Drewes and others (2002). Numbers depict depth estimates for: (1) porphyritic intrusive of Red Mountain at a depth of more than 400 meters; (2) possible intrusive near Lead Queen Mine; (3) possible intrusive near U.S. Mine; (4) possible intrusive that may be associated with the Washington Camp and Duquesne mineral districts; (5) possible intrusive that may be associated with Morning Glory Mine; (6) possible intrusive associated with Santo Nino Mine; and (7) possible intrusive associated with Four Metals Mine, which may be related to map unit Tgc (fig. 2, table 1). Locations of mines are shown in figure 2. 


\section{Conclusions}

An infinite number of solutions are available for all geophysical problems, but there is only one correct answer. Producing the best geophysical modeling requires that all known geologic information be incorporated into the model. Included is the knowledge that when looking at the Earth as a whole and possibly excluding some very old rocks, about onehalf of the rocks near the Earth's surface were formed when the Earth's magnetic field was in a state of reversed polarity. In small areas, this may not be the case. Likewise, it may be true in a small area that most of the rocks may have formed in a reversed magnetic field. Furthermore, tectonic events, such as repeated faults from extension, can rotate the natural remanent magnetism to arbitrary orientations.

In the Patagonia Mountains study area in southeastern Arizona, geological knowledge was incorporated into modeling by using rock physical properties, using known association of intrusive events, and incorporating information from existing mapped geology. Using this geological knowledge, a model of geology at depth was produced that may better represent actual conditions than previous models. This new model has major implications for undiscovered mineral resources in the study area. Contacts at the top of the concealed intrusive rocks are a likely area where concealed mineral deposits may be found, especially in regions where the overlying rock is a host rock for disseminated, or skarnrelated deposits, as in Mesozoic and Paleozoic rocks east of the Harshaw Creek Fault and continuing into the San Rafael Basin.

This new geologic model also may have implications for water resources. Although not the focus of this study, volcanic rocks in the Sonoita Basin can be simulated with reduced total magnetic intensity natural remanent magnetic field underlying relatively thin basin fill instead of the thick basin fill that is assumed to exist in the basin.

The complete Bouguer anomaly map of the Patagonia Mountains study area indicates that the proposed intrusive does have a positive gravity anomaly and is cut off on the east and north by faults. It also shows that this intrusive might extend farther to the northeast than its magnetic anomaly would indicate.

Euler depth estimates with a structural index of 0 along the Patagonia Fault generally agree with the depth estimates simulated by the model. They also show that the concealed Patagonia Fault southwest of the Patagonia Mountains is more complex than mapped. Additionally, Euler depth estimates with a structural index of 2 located many potential intrusive bodies that may be associated with both known and undiscovered mineralization.

\section{References Cited}

Berger, B.R., King, T.V.V., Morath, L.C., and Phillips, J.D., 2003, Utility of high-altitude infrared spectral data in mineral exploration-Application to Northern Patagonia Mountains, Arizona: Economic Geology, v. 98, p. 1003-1018.

Betts, N.K., Chongo, P., Dieter, N.L, Elliot, B.J., Geeslin, G.R., Henley, M.B., and others, 1998, Geophysical surveys near Patagonia, Arizona, Geophysics Field Camp: University of Arizona, Department of Mining and Geological Engineering, LASI-98-1, 76 p.

Blakely, R.J., and Simpson, R.W., 1986, Approximating edges of source bodies from magnetic or gravity anomalies: Geophysics, v. 51, no. 7, p. 1494-1498.

Butler, R.F., 1998, Paleomagnetism-Magnetic domains to geologic terranes, electronic edition: Tucson, University of Arizona, Department of Geosciences, http://www.geo. arizona.edu/Paleomag/book/.

Casto, D.W., 2001, Calculating depths to shallow magnetic sources using aeromagnetic data from the Tucson basin: U.S. Geological Survey Open-File Report: 2001-505, 231 p., http://pubs.er.usgs.gov/publication/ofr01505.

Clark, D.A., 1997, Magnetic petrophysics and magnetic petrology —Aids to geological interpretation of magnetic surveys: AGSO Journal of Australian Geology and Geophysics, v. 17, p. 83-103.

Cordell, L., and Grauch, V.J.S., 1985, Mapping basement magnetization zones from aeromagnetic data in the San Juan basin, New Mexico, in Hinze, W.J., ed., The utility of regional gravity and magnetic anomaly maps: Society of Exploration Geophysicists, p. 181-197.

Corn, R.M., 1975, Alteration-mineralization zoning, Red Mountain, Arizona: Economic Geology, v. 70, p. 1437-1447.

Davis, G.H., 1981, Regional strain analysis of the superposed deformations in southeastern Arizona and the eastern Great Basin: Arizona Geological Society Digest, v. 14, p. $155-172$.

Drewes, H., 1980, Tectonic map of southeastern Arizona: U.S. Geological Survey Miscellaneous Investigations Series Map I-1109, 2 sheets, scale 1:125,000. 
Drewes, H., 1996, Geology of Coronado National Forest, chap. B of du Bray, E.A., ed., Mineral resource potential and Geology of Coronado National Forest, southeastern Arizona and southwestern New Mexico: U.S. Geological Survey Bulletin 2083-A-K, p. 17-41.

Drewes, H., Fields, R.A., Hirschberg, D.M., and Bolm, K.S., 2002, Spatial digital database for the tectonic map of southeast Arizona: U.S. Geological Survey Geologic Investigations Series I-1109, http://pubs.usgs.gov/imap/ i1109/.

Gettings, M.E., 2002, An interpretation of the 1996 aeromagnetic data for the Santa Cruz basin, Tumacacori Mountains, Santa Rita Mountains, and Patagonia Mountains, south-central Arizona: U.S. Geological Survey Open-File Report 2002-99, 44 p., http://pubs.er.usgs.gov/ publication/ofr200299.

Gettings, M.E., and Bultman, M.W., 2014, Magnetic susceptibility data for some exposed bedrock in the western conterminous United States: U.S. Geological Survey Data Series 804,5 p., with graphical interface, http://dx.doi. org/10.3133/ds804.

Gettings, P.E., and Gettings, M.E., 1996, Modeling of a magnetic and gravity anomaly profile from the Dragoon Mountains to Sierra Vista, southeastern Arizona: U.S. Geological Survey Open-File Report 96-288, 13 p., 3 pls.

Gettings, M.E., and Houser, B.B., 2000 Depth to bedrock in the upper San Pedro Valley, Cochise County, southeastern Arizona: U.S. Geological Survey Open-File Report 00-138, http://pubs.usgs.gov/of/2000/of00-138/.

Geosoft, 2013, Oasis Montaj software: Geosoft Web site, accessed March 4, 2014, at http://www.geosoft.com/ products/oasis-montaj.

Grauch, V.J.S., and Cordell, L., 1987, Limitations on determining density or magnetic boundaries from the horizontal gradient of gravity or pseudogravity data: Geophysics, v. 52, no. 1, p. 118-121.

Graybeal, F.T., 1996, Sunnyside-A vertically preserved porphyry copper system, Patagonia Mountains, Arizona: Society of Economic Geologists Newsletter, no. 26, p. 1, and $10-14$.

Hagstrum, J.T., 1994, Remagnetization of Jurassic volcanic rocks in the Santa Rita and Patagonia Mountains, ArizonaImplications for North American polar wander: Journal of Geophysical Research, v. 99, no. B8, p. 15103-15113.

Hsu, Shu-Kun, 2002, Imaging magnetic source using Euler's equation: Geophysical Prospecting, v. 50, no. 1, p. 15-25.
International Geomagnetic Reference Field and Aeronomy, Working Group V-MOD, Participating members, Finlay, C.C., Maus, S., Beggan, C.D., Bondar, T.N., Chambodut, A., Chernova, T.A., and others, 2010, International Geomagnetic Reference Field-The eleventh generation: Geophysical Journal International, v. 183, no. 3, p. 1216-1230, doi:10.1111/j.1365-246X.2010.04804.x.

Koenigsberger, J.G., 1938a, Natural residual magnetism of eruptive rocks: Terrestrial Magnetism and Atmospheric Electricity, v. 43, no. 2, p. 119-130, doi:10.1029/ TE043i002p00119.

Koenigsberger, J.G., 1938b, Natural residual magnetism of eruptive rocks: Terrestrial Magnetism and Atmospheric Electricity, v. 43, no. 3, p. 299-320, doi:10.1029/ TE043i003p00299.

Lipman, P.W., and Sawyer, D.A., 1985, Mesozoic ash-flow caldera fragments in southeastern Arizona and their relation to porphyry copper deposits: Geology, v. 13, p. 652-656.

Morris, B., Ugalde, H., and Thomson, V., 2007, Magnetic remanence constraints on magnetic inversion models: The Leading Edge, Society of Exploration Geophysicists, August issue, p. 960-964.

Neel, Louis, 1955, Some theoretical aspects of rockmagnetism: Advances in Physics, v. 4, no. 14, p. 191-243.

Nicholls, G.D., 1955, The mineralogy of rock magnetism: Advances in Physics, v. 4, no. 14, p. 113-190.

Phillips, J.D., 1997, Potential-field geophysical software for the PC, ver. 2.2: U.S. Geological Survey Open-File Report 97-725, $34 \mathrm{p}$.

Phillips, J.D., 2002, Processing and interpretation of aeromagnetic data for the Santa Cruz Basin - Patagonia Mountains area, south-central Arizona: U.S. Geological Survey Open-File Report 02-98, http://pubs.usgs.gov/ of $/ 2002 / 0098 /$.

Phillips, J.D., 2007, Geosoft eXecutables, GX's developed by the U.S. Geological Survey, version 2.0, with notes on GX development from Fortran code: U.S. Geological Survey Open-File Report 2007-1355, 111 p.

Runcorn, S.K., 1955, Rock magnetism-Geophysical aspects: Advances in Physics, v. 4, no. 14, p. 244-291.

Rystrom, V.L., Finn, C.A., and King, T.V.V., 2002, Geologic interpretation of aeromagnetic maps in the Santa Cruz Basin-Patagonia Mountains area, south-central Arizona: U.S. Geological Survey Open-File Report 02-100, http:// pubs.usgs.gov/of/2002/0100/. 
Saltus, R.W., and Blakely, R.J., 2011, Unique geologic insights from "non-unique" gravity and magnetic interpretation:

GSA Today, v. 21, no 12, p. 4-11, doi:10.1130/G136A.1.

Simons, F.S., 1972, Mesozoic stratigraphy of the Patagonia Mountains and adjoining areas, Santa Cruz County, Arizona: U.S. Geological Survey Professional Paper 658-E, $23 \mathrm{p}$.

Simons, F.S., 1974, Geologic map and sections of the Nogales and Lochiel Quadrangles, Santa Cruz County, Arizona: U.S. Geological Survey Miscellaneous Investigations Series Map I-762, scale 1:48,000.

Vikre, P.G., Graybeal, F.T., Fleck, R.J., Barton, M.D., and Seedorf, E., 2009, Succession of magmatic-hydrothermal events in the Patagonia Mountains, Arizona [abs.]:

Geological Society of America Abstracts with Programs, v. 41 , no $7 .$, p. 524 .
Vine, F.J., and Matthews, D.H., 1963, Magnetic anomalies over oceanic ridges: Nature, v. 199 , no. 4897, p. 947-949, doi:10.1038/199947a0.

U.S. Geological Survey, 2000, Three aeromagnetic surveys in South Central Arizona-A web site for distribution of data, On-line edition: U.S. Geological Survey Open-File-Report 00-155, http://pubs.usgs.gov/of/2000/ofr-00-0155/.

Urquhart, T., 1988, Decorrugation of enhanced magnetic field maps, in Proceedings of the 58th Society of Exploration Geophysicists Annual International Conference and Exhibition, Tulsa, Okla., Expanded Abstracts, p. 371-372.

Yaghoobian, A., and Boustead, G.A, 1993, Object delineation using Euler's homogeneity equation-Location and depth determination of buried ferro-metallic bodies, in Proceedings of the Symposium on the Application of Geophysics to Engineering and Environmental Problems: SAGEEP '93, Orlando, Fla., v. 2, p. 613-632. 

Publishing support provided by the U.S. Geological Survey Science Publishing Network, Tacoma Publishing Service Center

For more information concerning the research in this report, contact the Director, Geology, Minerals, Energy, and Geophysics Science Center U.S. Geological Survey

520 N. Park Avenue

Tucson, AZ 85719

http://geomaps.wr.usgs.gov/gmeg/ 
